\title{
Energy Availabilities for State and Local Development: A Methodological and Data Overview
}
P. L. Rice
D. P. Vogt 


\section{DISCLAIMER}

This report was prepared as an account of work sponsored by an agency of the United States Government. Neither the United States Government nor any agency Thereof, nor any of their employees, makes any warranty, express or implied, or assumes any legal liability or responsibility for the accuracy, completeness, or usefulness of any information, apparatus, product, or process disclosed, or represents that its use would not infringe privately owned rights. Reference herein to any specific commercial product, process, or service by trade name, trademark, manufacturer, or otherwise does not necessarily constitute or imply its endorsement, recommendation, or favoring by the United States Government or any agency thereof. The views and opinions of authors expressed herein do not necessarily state or reflect those of the United States Government or any agency thereof. 


\section{DISCLAIMER}

Portions of this document may be illegible in electronic image products. Images are produced from the best available original document. 


\section{Printed in the United States of America. Available from National Technical Information Service \\ U.S. Department of Commerce \\ 5285 Port Royal Road, Springfield, Virginia 22161 \\ Price: Printed Copy $\$ 4,50$; Microfiche $\$ 3.00$}

This report was prepared as an account of work sponsored by the United States Government. Neither the United States nor the Energy Research and Development Adminıstratıon/United States Nuclear Regulatory Commission, nor any of their employces, nor any of their contractors, subcontractors, or their employees, makes any warranty, express or implied, or assumes any legal liability or responsibility for the accuracy, completeness or usefulness of any information, apparatus, product or process disclosed, or represents that its use would not infringe privately owned rights. 


\begin{abstract}
Contract No. W-7405-eng-26
ENERGY AVAILABILITIES FOR STATE AND LOCAL DEVELOPMENT:

A METHODOLOGICAL AND DATA OVERVIEW
\end{abstract}

P. L. Rice

D. P. Vogt

Regional and Urban Studies Section

Energy Division

Research sponsored by the Economic Development Administration of the

U.S. Department of Commerce

Date Published: June 1977

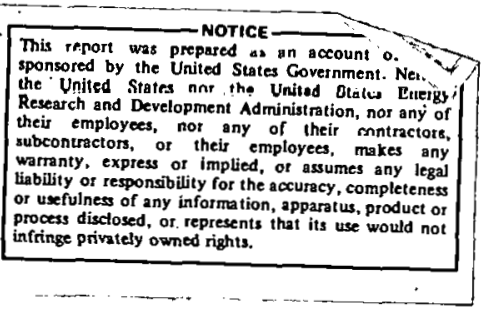

OAK RIDGE NATIONAL LABORATURY

OAK RIDGE, TENNESSEE 37830

operated by

UNION CARBIDE CORPORATION

for the

ENERGY RESEARCH AND DEVELOPMEN'I ADMINISTRATION

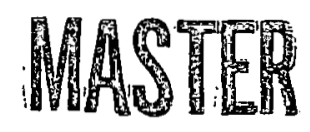


THIS PAGE

\section{WAS INTENTIONALLY LEFT BLANK}


ABSTRACT . . . . . . . . . . . . . . . . . . . . v v

I. INTRODUCTION . . . . . . . . . . . . . . . . . . 1

A. Purpose of Report . . . . . . . . . . . . . . . . . 1

B. Background to Research Problem . . . . . . . . . . 1

C. Organization of the Report . . . . . . . . . . . 2

II. A METHODOLOGICAL OVERVIEW . . . . . . . . . . . . . 3

A. Research Goal ................... 3

B. Summary of Information Detail . . . . . . . . . . . 3

C. Regional Energy Statements . . . . . . . . . . . . 5

D. Projecting Regional Energy Use and Availability . . . . 5

a. Projecting Energy Use . . . . . . . . . . . 7

b. Projecting Energy Availability . . . . . . . . 7

III. FUEL SOURCES AND ENERGY FORMS . . . . . . . . . . . . . 9

A. Introduction . . . . . . . . . . . . . . . . 9

B. Coal Production . . . . . . . . . . . . . . 9

C. Crude Oil Production . . . . . . . . . . . . . 9

D. Natural Gas Production . . . . . . . . . . . 10

E. Petroleum Refining . . . . . . . . . . . . . 12

F. Natural Gas Processing . . . . . . . . . . . 13

G. Electricity Generation.............. 14

IV. ENERGY USE: DATA SOURCES AND ALLOCATION PROCEDURES . . . . 16

A. Introduction . . . . . . . . . . . . . . . 16

B. Regionalization of Energy Consumption . . . . . . . 21

V. SUMMARY AND CONCLUSIONS . . . . . . . . . . . . . . 35

A. Summary of Progress . . . . . . . . . . . . 35

B. Proposed Future Activities . . . . . . . . . . 37

FOOTNOTES . . . . . . . . . . . . . . . . . . . . 39

APPENDIXES .......................... . . . . 43 


\section{THIS PAGE}

\section{WAS INTENTIONALLY \\ LEFT BLANK}


This report presents the methodology utilized by ORNL staff on a research project funded by the Economic Development Administration to determine energy resource extraction, energy production, and energy use for seven fuel types and four final consuming sectors for Bureau of Economic Analysis (BEA) areas and states for the years 1972, 1973, and 1974. The basic approach used to assess regional energy availability involved the collection and organization of data on a county or field basis, and the subsequent aggregation of this data to BEAs and states. For energy use data, the approach was to allocate state level data to county groups which could then be assembled into BEAs.

This report also describes the methodology used to forecast regional energy conditions in 1980 and 1985 consistent with the 1976 National Energy Outlook of the Federal Energy Administration. ${ }^{1}$ Energy use was projected using an allocation procedure based on projected levels of population and employment. Regional energy availability was projected based on historical energy supply patterns. In addition, the report discusses the format of the data volumes that will be subsequently released, as well as the proposed activities scheduled for completion during the third year of the EDA project. 


\section{INTRODUCTION}

\section{A. Purpose of Report}

This report describes an ongoing research program sponsored by the Economic Development Administration at the Oak Ridge National Laboratory to construct regional statements of state and substate energy use and availability. The purpose of these statements is to create a nationally consistent medium for monitoring and projecting changes in energy delivery and consumption patterns that may affect regional economic development: Particular emphasis will be placed upon key energy forms whose shortage. may inhibit economic activity or constrain new development.

This report also presents our progress thus far in the project. During the first year of the program, ending June 30, 1976, we concentrated on establishing the methodology required and collecting the necessary data for 1972. During this second year of the project we have collected data forr 1973 and 1974 and focused on the development of regional energy statements and their incorporation into a projection methodology capable of assessing future energy uses and availabilities.

\section{B. Background to Research Problem}

Interest in substate energy use and availability has grown significantly in recent years. Barring a second international oil embargo, or similar exogenous event, the national economy can accommodate marginal changes in energy supplies and prices. The problem which arises is that minimal national changes are frequently distributed unequally among subnational areas. Marginal decreases in the production or availability of particular fuels often represent distinct shortages among some subnational regions. Solutions designed to remedy these energy shortfalls are also likely to be concentrated with regard to impacts. Thus, a regional evaluation of energy-related economic impacts appears appropriate and timely to assist the Economic Development Administration in developing its grant-in-aid investment strategy.

The analysis of regional economic development and its relationship to the availability of energy requires a substantial adaption of the economists' standard tools, largely due to the inadequacy of existing regional energy data bases: The state of the art in energy consumption data analysis remains at a relatively low level. For example, it is still difficult to trace energy supplies from point of extraction to final use due to the diversity of marketed energy forms, production intermediaries, and final users. Available information is frequently decentralized, incomplete, and even when gathered, inconsistent. Thus, to conduct meaningful regional analysis, a significant effort is necessary to construct an adequate regional energy-economic information base. 
The lack of sound information sometimes leads to the development of well-defined methodological techniques that can be used to overcome data shortfalls. Although these tools are becoming operational at the national level, the "trickle down" process to link regional energy issues and regional economic activity with national trends has yet to be fully developed. ${ }^{2}$ To construct a suitable regional analysis system we have focused on basic elements and on the particular way in which the composition is likely to affect energy usage at the regional level.

As a result, we have developed a consistent format for gathering and estimating national energy data on a regional grid. Moreover, we have developed a viable structure for making regional projections of energy use and availability. A primary objective has been to empirically link existing data structures with economic activity and to subsequently apply this system to identify possible structural energy shortages at a subnationa1. jeve?.

\section{Organization of the Report}

The remainder of the report is divided into four major chapters. Chapter II presents an overview of the methodological design developed to guide the research project. The section includes a statement of project goals, a summary of data items and spatial grid, and a brief examination of the manner in which energy uses and availabilities will be projected and analyzed. Chapter III discusses the data sources and conventions used in constructing the information sets for energy forms and fuel sources. Chapter IV discusses the energy use calculations. Because less data is available for energy use than for energy production at the substate level, we have set out the steps used to generate these statistics in some detail. Chapter $\mathrm{V}$ contains an evaluation of our work. to date as well as anticipated progress during the third year of the program. 


\section{A METHODOLOGICAL OVERVIEW}

\section{A. Research Goal}

The goal of this research is to develop a regional energy procedure to analyze historic and projected regional differences in the demand and availability of energy. This procedure is essential in order to make valid historic, current, or projected comparisons among regions.

To achieve the desired level of consistency of treatment of both historic and forecasted data would require considerable resources. Since such resources are not available in the current project, several simplifying assumptions were made to develop our methodological approach, as will be explained below.

\section{B. Summary of Information Detail}

The procedure developed is designed to. report seven energy forms for four final consumption sectors across a regional grid, as shown in Table 1. This should provide sufficient detail for a comparison of regional energy patterns. In addition, five fuel sources are considered, though for coal and gas the fuel source and form are essentially identical. Energy forms are defined as products that serve energy end uses. Fuel sources are defined as inputs to energy forms. In addition, three transformation sectors are considered: (1) petroleum refineries, which transform crude oil into petroleum products; (2) natural gas processing plants, which transform natural gas and lease condensate into LPG, propane, and other products; (3) electric utilities, which transform coal, natural gas, uranium, hydro-power, and several petroleum-based energy forms into electricity.

The aggregation of consuming sectors chosen for this analysis generally corresponds to that used by the Bureau of Mines. ${ }^{3}$ Although other combinations were possible, we chose to combine residential and commercial users to be consistent with the Bureau of Mines. Combining sectors also facilitated the use of the aggregated forecasts of the Federal Energy Administration (FEA) as control totals. The transportation sector is treated separately because of its relative importance as an energy user. More detail by fuel and by sector than reported has been utilized in the empirical analysis. The level of detail retained is, however, constrained by the availability of historic data from the Bureau of Mines and the level of aggregation of forecasted data from the FEA scenarios. Because of the differences in the level of detail in each data set, the reporting units listed in Table 1 were selected as being most appropriate for reporting both the historic and forecasted data on a consistent basis.

The regional grid chosen for this analysis is Bureau of Economic Analysis (BEA) areas, developed by the Department of Commerce. ${ }^{4}$ Two considerations governed this choice: (1) it is a goal of the analysis to 
Table 1. Summary of Information Detail

A. Classification of Fuel Sources and Energy Forms

\section{Fuel Sources}

\section{Coal}

Natural Gas

Crude 0 il

Uranium

Hydropower

\section{Energy Forms}

Coa1

Natural Gas

Distillate 0il

Residual 0il

Gasoline

Other Petroleum Products

Electricity

B. Classification of Transformation and Final Consuming Sectors

\section{Transformation Sectors:}

Petroleum Refineries

Convert Crude Oil into

Petroleum Products

Natural Gas Processing Plants

Convert Natural Gas and

Lease Condensate into

NaturaI Gas Products

Electric Dtilities

Convert Uranium, Hydrop.jwer,

Natura Gas, Coal, and jeveral

Petroleum Products into

Electr-city

\section{Final Consuming Sectors:}

Residential, Commercial, and Agricultural

Manufacturing and Mining

Transportation

Miscellanecus Uses 
project future levels of energy consumption using an ORNL employmentpopulation projection system (MULTIREGION ${ }^{5}$ ) that operates on the BEA spatial grid; and (2) BEA areas conform closely to the concept of load centers commonly applied in electricity consumption analysis.

These 173 BEA areas (shown in Figure 1) can be easily disaggregated by county groups into 250 BEA portions, referred to as subregions, which are consistent with both BEAs and states. These areas are generally smaller than various types of homogeneous regions such as Petroleum Administration Districts, Coal Provinces, or heating degree day areas, familiar in other energy accounting systems. BEA areas conform purposefully to labor market boundaries and are thus well suited to an analysis of energy and economic development. Moreover, the selected grid is based on a system of functional economic regions for which reliable economic data is available.

\section{Regional Energy Statements}

Regional energy statements are an accounting of energy flows within a spatial unit during a period of time. Annual flows are used for the purpose of this study. Conceptually, such a statement might be prepared in a number of units-physical units, dollar values, thermal equivalent units, etc. We have chosen to gather the basic information in terms of physical units. This choice was dictated primarily by data availability, and we will convert these quantities to thermal equivalent units (BTUs) in the regional energy statements. Using this accounting format, we will analyze energy at the point of extraction, points of processing, and points of final consumption using both historic and forecasted values. Additional detail regarding the conventions adopted in preparing these statements is described below. ${ }^{6}$

\section{Projecting Regional Energy Use and Availability}

To project future regional energy consumption at the appropriate grid and analyze the manner in which these needs will be met, we will project regional energy use through a system which allocates national control totals of energy use to regions using socioeconomic activity measures. These measures, such as employment levels, are consistent with those used in generating the national energy control totals. With allocations of demands complete, we then analyze alternative ways of satisfying projected demands. This contrasts with the more traditional econometric method of estimating demand and supply relationships separately, and imposing equilibrium conditions through a price adjustment mechanism.

This ORNL approach has been adopted for several reasons, most of which center around the inherent difficulty of constructing a spatially distributed general equilibrium model: (1) sufficient information to conduct traditional econometric demand analysis is not available at a detailed regional grid level; and (2) it is difficult to construct a 
ORNL-DWG 76-2734

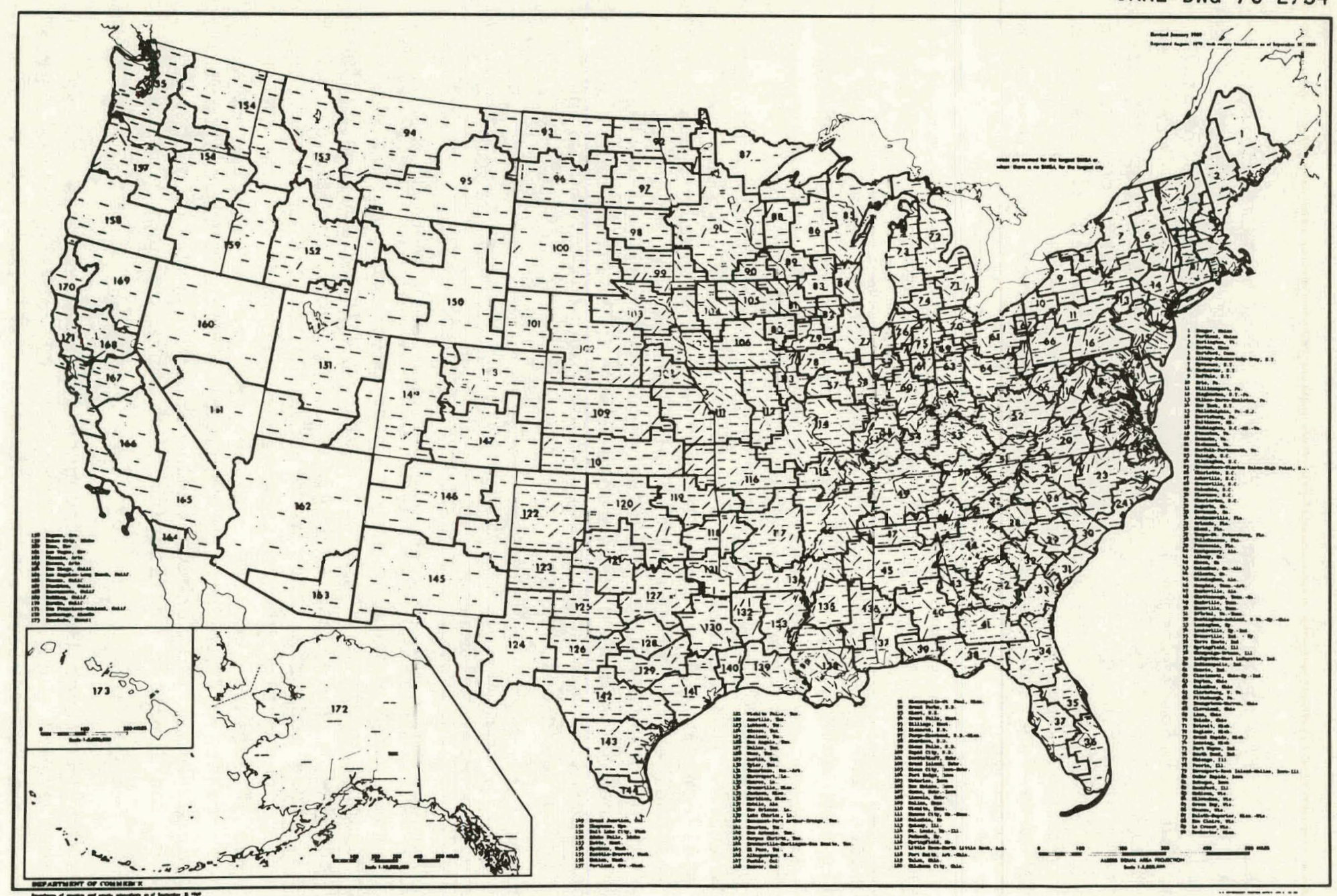

Figure 1. BEA Areas in the United States. 
spatial supply analysis which permits disequilibrium solutions. Thus, we intend to project energy use based upon the composition of socioeconomic activities and then analyze the supply system as it is structured to respond to desired levels of energy use.

\section{a. Projecting Energy Use}

Four steps are involved in projecting regional energy use:

1. Choose a national economic scenario;

2. Choose a national energy use scenario;

3. Regionalize the economic scenario;

4. Regionalize the energy scenario based on regional economic and population levels.

Although these steps are conceptually separate, they combine the results from several economic models and must be carried out consistently. It is particularly critical that the economic and energy scenarios be consistent. We have chosen to use the base case forecasts of energy consumption published by the FEA as energy control totals. We will adopt a set of national economic scenarios consistent with those driving the FEA model and based on the "Control Long 5/75" forecast of DRI. " For the base case, we will choose an INFORUM forecast that is consistent with the energy control totals. ${ }^{8}$ The INFORUM forecast of national economic activity is then regionalized by MULTIREGION, a regional economicdemographic projection-simulation model under development at ORNL. At present, however, we have not completed work permitting aggregation of MULTIREGION forecasts to the state level. Thus, the regional and economic-demographic projections from OBERS have been substituted in the regionalization scheme as an interim approach.

\section{b. Projecting Energy Availability}

In contrast with the energy use analysis, which is designed to develop regional forecasts of national energy demands, our supply analysis is designed to answer the question of whether projected regional energy availabilities are adequate to meet projected regional levels of energy use. Ultimately we will determine which regions will have shortfalls in energy supply and the magnitude of these shortfalls. We will then rank the availability of specific fuels in specific regions relative to each region's projected level of energy use. This analysis involves five steps:

1. Determine the present location of fuel sources;

2. Determine the present location of energy forms;

3. Determine the region specific role of imported energy;

4. Examine the capacity of regional transport systems;

5. Reconcile projected energy uses and availabilities. 
The first two steps of this process are straightforward and will be accomplished through the preparation of the historical energy statements. This information will provide the level of activity in fuel source extraction and energy production, as well as provide a brief time trend of these levels. If continued over future years, these statements should provide a valuable means of tracing energy supplies and their implications for regional economic development. The third step, examining imports, is more difficult, given the lack of appropriate data at the subnational level. We have, however, gathered information as to the ownership, location, and diameter of crude oil, petroleum product, LPG, and natural gas pipelines on a county basis which will soon be available in a machine-readable data base.

In conducting our research, we intend to place special emphasis on those energy forms where immediate srarcity is at issue, notably natural gas. An attempt will be made, nonetheless, to provide a balanced treatment of the supply side, with the overall aim of identifying whether the availability of specific energy forms will likely influence future patterns of regional economic development. 


\section{FUEL SOURCES AND ENERGY FORMS}

\section{A. Introduction}

A major portion of our activity has been devoted to preparing a regional data base containing energy use and production information. This chapter discusses the data gathered for fuel sources and energy forms, while the following chapter discusses energy use data. The data discussed in these chapters have now been collected for 1972 and will be reported as a separate volume. The 1973 and .1974 supply data have also been collected, and these volumes will be forthcoming when the energy use data at the state level is available.

\section{B. Coal Production}

For the purposes of this study, coal is defined as an aggregate commodity including bituminous, lignite, and anthracite coal. In 1974 there were 28 states with coal reserves, but only 24 states engaged in coal production. Montana, Illinois, and Wyoming led the nation with approximately $52 \%$ of the remaining coal reserves, though these three states were not the leading coal producers. Indeed, the bulk of production (54\%) emanated from Kentucky, West Virginia, and Pennsylvania. If no new reserves were to be found, and production were to remain constant, the nation currently has several hundred years of coal production remaining.

Complete information on all mines producing 1000 tons per year or more in 1972 and 1973 is given in the Minerals Yearbook and various Bureau of Mines information circulars at the county level. ${ }^{9}$ The 1974 county level detail was taken from the 1976 Keystone Coal Industry Manual. ${ }^{10}$ All quantities represent net tons of marketable coal and exclude washery and other refuse. Statistics are based on the annual reports of production and mine operation furnished by individual coal producers to the Bureau of Mines.

Coal production in 1980 and 1985 was determined based on the detailed coal supply model of FEA (\$13-oil base case scenario) and historical production patterns. Twelve regional control totals were allocated to counties based on remaining reserves in each state and historical production in each county in 1.973 and 1974 . The county data were then aggregated to BEAs and states.

\section{Crude Dil Production}

There were 31 states engaged in the production of crude oil and lease condensate in 1974. The number of oil wells drilled has been declining since 1956, but has recently begun to increase in response to the two-tier price system enacted by the FEA in May 1973. Oil production has been declining since 1970, at least partially due to producers' 
inability to discover any major new fields coupled with the abandonment and depletion of older fields. Texas and Louisiana lead the oil-producing industry with $62 \%$ of total domestic crude production. The balance of domestic demand must be met by foreign imports, however, and these imports amounted to $40 \%$ of domestic production in 1974 . The reserve-production ratio, declining since 1949 , was $11: 1$ in 1974 , implying that if oil production continues at the same annual rate and no new discoveries are made, we will deplete domestic oil resources by 1986.

State estimates of 1972 oil production by county or field were obtained from Arkansas, Kansas, Louisiana, Oklahoma, and Texas. ${ }^{11}$ When these state totals were inconsistent with those reported by the Bureau of Mines, the individual state reports were assumed to be the correct estimates and superseded Bureau of Mines estimates. County-level production was given in the Minerals Yearbook for Alabama, California, Colorado, Illinois, Kentucky, Michigan, Nebraska, New Mexico, North. Dakota, Utah, and Wyoming and field-production for Alaska, Indiana, Mississippi, and Nevada. Oil fields were identified and located within counties to provide BEA production estimates. Since oil fields are not constrained to county, BEA, or even state boundaries, the dominant BEA was credited with total field production. In most cases this geographic area was sufficiently large to encompass the field in question.

Specific data were available for determining $98 \%$ of 1972 oil production. The remaining $2 \%$ was allocated to Tennessee, West Virginia, New York, Arizona, Missouri, South Dakota, Florida, Montana, Ohio, and Pennsylvania based on statistics provjded by the Bureau of Mines and the Oil and Gas Journal, which publishes information on the production of large oil tields. 'I 'This data base was supplemented by examining the location of oil and gas fields in these states to restrict allocation to those counties known to have hydrocarbon deposits. ${ }^{13}$

Various state agencies were polled to obtain estimates of production in 1973 and 1974. Virginia, West Virginia, and New York were the only states which failed to provide either field or county level information. Specific information was available, therefore, for $99.9 \%$ of production during these two years. The cooperating state agencies who responded to our survey are enumerated in the data appendix. It is noted that the estimates of Mississippi were at such variance with those of the Bureau of Mines that they were used to construct weights to allocate the state production estimate of the Bureau. This decision was made to capitalize on the county-specific information being provided while retaining the consistency of the energy statistics in the Minerals Yearbook.

\section{Natural Gas Production}

Natural gas was produced from both oil (assoclated) and gas (nonassociated) wells in 30 states in $1974 . .^{14}$ Both the number of gas wells drilled and the amount of gas production have been declining since 1970. The production of natural gas, $75 \%$ of which comes from Texas and Louisiana, has exceeded new discoveries during six of the 
previous seven years. Natural gas reserves declined $19 \%$ over that period. Indeed, if annual production were to remain at the 1974 rate and no new discoveries of natural gas were made, the reserve base would be depleted by 1986 . Approximately $4 \%$ of domestic demand for natural gas was satisfied by foreign imports shipped by pipeline from Canada.

Efforts to supplement natural gas supplies through the gasification of liquid fuel continue. In 1974, there were 11 such operational synthetic gas plants and an additional 3 plants being planned. ${ }^{15}$ There were 5 pilot projects for the development and testing of processes for the production of high BTU gas from coal at yearend 1974. Gas usage has been declining, especially for electricity production, but it is primarily a consequence of the increase in curtailments of firm deliveries by pipelines rather than a surge in conservation efforts.

State publications of 1972 gas production by county or field were available for Arkansas, Kansas, Louisiana, Oklahoma, and Texas. The estimates of Louisiana, Mississippi, and Texas were used as weights in allocating the Bureau of Mines state control totals. Some of this discrepancy is attributed to the fact that Louisiana did not include offshore production and all three states distinguished casinghead gas, net production of natural gas, and condensate. The Minerals Yearbook provided county or field information for California, New Mexico, Colorado, and Wyoming. Some $96 \%$ of total gas production was known with certainty, such that only a small percentage of the total was based on ad hoc allocation procedures. In Arizona, for example, only one county (Apache) has producing oil and gas wells. In Tennessee, production occurs in only three counties, and in Missouri the bulk of production is in St. Louis County. Information on Virginia, West Virginia, Maryland, and New York was gained from examination of oil and gas fields in these states and careful scrutiny of the description of minerals production by the Bureau of Mines.

Production in Alabama, Florida, Illinois, Indiana, Kentucky, Michigan, Mississippi, Montana, Nebraska, North Dakota, Ohio, Pennsylvania, and Utah was determined on the basis of the characteristics of drilling activity in each. Data on each of the producing states as to total footage drilled, the number of exploratory. and proven oil and gas wells, the percentage of oil produced from associated versus nonassociated wells, and the success ratio associated with each type of drilling activity were available. This information was utilized in a regression analysis to determine the relative importance of each variable in determining actual production in the state. The coefficients obtained were applied to these drilling statistics which were available on a county basis for the aforementioned states in the Minerals Yearbook. The allocation scheme calculated a weight for each county based upon the nature of the drilling activity and the importance of each characteristic to actual production. It was felt that all relevant information was taken into account and that the substate estimates thus derived are credible. 
Most of the 1973 and 1974 data were obtained from the producing states who contributed estimates of oil production. Natural gas production in Indiana, Kentucky, New York, North Dakota, Pennsylvania, Virginia, and West Virginia was allocated to counties based upon the 1972 level of production in each. These states collected extensive oil production data (with the exception of Virginia and West Virginia), but did not estimate gas production at the same level of detail. As with the estimates of oil production, when discrepancies occurred between state estimates and Bureau of Mines estimates, the state estimates were assumed to be correct.

Oil and gas projections for 1980 and 1985 were determined using eronometric analysis and national control totals from the detailed oil and gas supply models of FEA (\$13-oil base case scenario). Historical state production patterns were assumed to be expldined by cumulative production, proved reserves, indicated and inferred reserves, and/or the ratio of cumulative production to ultimately recoverable reserves. An examination of partial correlarton coefficients indicated that $95 \%$ of the variation in 1974 .oil production and 98\% of the variation in 1974 gas production was explained by the estimated ultimate recovery of the reserves of each. Individual BEA projections were determined based on average historical production patterns exhlbited during 1972, 1973, and 1974. The regional projections thus embody the significance of finding rates, drilling costs, the domestic price of crude, the declining reserve base, as well as historical production patterns.

\section{E. Petroleum Refining}

The nation's 259 operating refineries processed 4.4 billion barrels of oil in $1974,29 \%$ of which was obtained from foreign sources. In Hduiliul, 272 million barrclc of natural gas 1 iquits from labulal gas processing plänts were prucessed by petroleum rcfincrc. Taxas, Lnuiaiana, and California led the nation with $39 \%$ of the refineries and $51 \%$ of the crude distillation capacity. In addition to $15 \mathrm{mbll} / \mathrm{day}$ Lliruighput capacity, most refiners have catalytic, thermal, coking, and hydro-cracking capacities for refining crude oil.

The primary output from the refining process is gasoline, which accounts for approximately $46 \%$ of the yield from a barrel of ciule input. Only 3\% of the domestic demand for gasoline is met by foreign imports. Gasoline production by stace is published dilidilly by the Buroau of Minco, and thle was the basir tata source for all refining outputs. In some instances, the Bureau aggregates production from several states for reporting purposes. In such cases, the amount of crude runs to stills, available by state, was used to disaggregate the lump sum totals. Refining capacity, available by plant, was relied upon to disaggregate any lump sum figures reporled for crude runs to ilille, a measure of the crude throughput of the refiner. ${ }^{16}$ Production of gasoline by county was determined by constructing a weight based on both plant capacity and state-level crude throughput, and then applying this weight to the multi-state total. 
Distillate oil accounts for $22 \%$ of the yield of a barrel of crude, with $10 \%$ of its domestic demand being met by foreign imports. The other major products are residual oil ( $9 \%$ of the yield) and jet fuel ( $7 \%$ of the yield). Approximately $59 \%$ of the domestic demand for residual oil is met by foreign imports, and $16 \%$ of the domestic demand for jet fuel is met by imports.

The output of these and other petroleum products are reported by refining district (there are 11 districts) rather than by state. These districts not only lump states together, but occasionally divide states as well. The county production of distillates, residual oil, and jet fuel was determined by using the county production of gasoline as a weight to allocate shares of the district totals. This weight incorporates information as to individual plant capacity, state crude throughput, and actual gasoline output. Some refineries, of course, produce only asphalt or coke, and in these cases this procedure was not applied.

The significance of incorporating both capacity and throughput into the determination of petroleum product output levels is based on the technical relationship which exists between crude oil input and refined petroleum output. Yields seldom vary over $6 \%$ to $7 \%$ and generally vary only in response to seasonal changes in product demands (i.e., there is a greater demand for distillate heating oil in the winter), rather than different producing characteristics of refiners. The actual throughput of crude oil is important since few refiners are capable of operating at full capacity.

Projections of processed oil and NGL and petroleum product production in 1980 and 1985 were based on projected refinery capacity and the refinery linear-programming model employed by FEA (\$13-oil base case scenario), which provides control totals for seven refining regions. Announced planned expansions and additions to capacity supplemented information on refining capacity by plant in January 1977. These projected capacity estimates were used as weights to allocate the refining district projections of FEA. The county projections were then aggregated to BEAs and states.

\section{F. Natural Gas Processing}

There were 768 natural gas processing plants in operation in 1974 according to the Oit and Gas Joumal, and these plants received approximately $90 \%$ of the natural gas marketed for sale. The long-term trend of annual increases in processing capacity came to a halt in 1971 and has been declining ever since. The, center of the industry is lorated in Texas and Louisiana, which have $63 \%$ of the plants and $61 \%$ of the total capacity in the United States. Approximately $47 \%$ of the natural gas liquids produced by processing plants are used by refiners as input into the production of gasoline, distillates, residual oil, etc. Of the residue gas, $79 \%$ was shipped to pipeline transmlssion companies, and $11 \%$ was shipped directly to consumers. 
Annual reports containing information as to the number of plants, their capacity, throughput, and production are submitted to the 0 ir and Gas Joumal when capacity exceeds 75 mmcf daily. ${ }^{17}$ These served as primary data sources for determining processing activity and supplied specific information in 1972 and 1973 on $76 \%$ of the total gas throughput. A complete survey of all plants was conducted in 1974 and published in the 1975 International Petroleum Encyclopedia. ${ }^{18}$ The data are given alphabetically by plant and were aggregated by counties to serve as the basis for allocating the capacity of the smaller plants (less than 75 mmcf daily) in 1972 and 1973.

Since a complete survey was not available for 1972, some simplifying assumptions were made to determine county-level throughput and production. If the number of operating plants was unchanged between 1972 and 1974 , the assumption was made that these were the same plants. It was then assumed that the county had the same share nf the state's capacity in 1972 as in 1974. This share was then applied to the unallocated portion of the 1972 capacity for the state. The output of processing plants is sent to refineries for use as feedstock and to ultimate consumers. The estimated share of capacity was used for the allocation of the output of the smaller plants, which was then adjusted by the proportion of output going directly to consumers. Throughput, defined to include extraction loss, gas used at the plants, returned to formations, or vented and flared, was similarly adjusted by the proportion of output going directly to consumers and allocated to smaller plants based on their capacity.

When the number of plants in operation in 1974 in a given state or county was greater than in 1972, these plants were simply subtracted from Llie 1974 tocal before the weights were constructed. Generally, however, Lhe number of plants in $19 \% 4$ was less than the number in 197.2, and when the throughput of the plant was less than 75 macf daily, there was no way to determine with certainty whirh plant had ceased operation during the two-year period. Since the number of plants and total capacity represented in these cases was relatively small, it was felt that the potential error generated by the ad hoc procedures employed was minimal. It is stressed that in all cases the state control totals served to constrain the arbitrary allocations to plants or counties.

\section{G. Elcctricity Generation}

In 1974 there were 36 nuclear plants, 1,156 hydro plants, and 2,443 fossil fuel plants in nperation in the United Statco gcnerating aprroximately $6 \%, 16 \%$, and $78 \%$, respectively, of the total electricity generated in the nation. Illinois currently has the largest share of nuclear capacity, followed by South Carolina, New York, Connecticut, Wisconsin, and Florida. Together these states accounted for $65 \%$ of all nucleargenerated electricity in 1974. The majority of the hydro capacity is located on the Pacific coast, particularly in the state of Washington. The South generated only $7 \%$ of its electricity with hydro-power in 1974 : Fossil fuel plants are more randomly distributed throughout the nation. 
In 1974 , coal was used for $57 \%$ of steam generation, natural gas for $22 \%$, and petroleum products for $21 \%$. The current trend appears to be toward coal and nuclear, and away from petroleum and gas.

The spatial location of electricity generation can be obtained by aggregation of plant level data. With the acquisition of an historic generation (and fuel use) data series for each utility plant, provided by the FPC from their "Form 4" series, the BEA regional totals can be obtained by accumulating the generation of each nuclear, hydro, and fossil fuel plant located within a BEA. ${ }^{20}$

ORNL has updated another data set obtained from the FPC (Generating Unit Reference File) such that all plants are located by state, BEA, and county. ${ }^{21}$ This data series also includes planned capacity expansions (new plants) and retirements, as well as existing capacity. Given the assumed heat rates and load factors used by FEA in their forecasts, the amount of electricity generation and fuel consumption of each plant that is expected to be on line in 1980 and 1985 will be estimated. Estimated generation at the plant level will then be adjusted to be consistent with FEA forecasts at the census level. The "adjusted" plant data.will be aggregated then to the BEA level to provide projected spatial patterns of generation and fuel use. 


\section{ENERGY USE: DATA SOURCES AND \\ ALLOCATION PROCEDURES}

\section{A. Introduction}

This chapter describes the procedures developed to regionalize historic and forecasted energy consumption data to a BEA grid. The energy production data was obtained from gathering and reorganizing very detailed regional information such as that from oil and gas fields. Information on energy use, however, is not available below the state level. Thus, a procedure to allocate state level information to a substate grid, based on a series of energy sensitive welghls, was developed to generate the historic energy cunsumpliuin data jerico.

This procedure lends itself to regional allocation of national scenarios of energy use, providing a simple, consistent method for forecasting $\mathrm{BEA}$ energy consumption estimates based on the national FEA energy scenarios. The baseline historical data for 1972 has been completed, and the results will be reported as a series of regional energy statements.' It is anticipated that this data series wit1 be extended as the basic data become available. Such statements for the forecast years 1980 and 1985 will also be published In fuithcoming volumes.

The goal of the energy consumption analysis is to identify patterns of energy consumption at the BEA level according to the use and fuel categories previously shown in Table 1 . 'The caregorles sliuwn in Tablc 2 will be used in the reglonal energy statements. (Th1s talle is explaincd in detail in Appendix B). The data presented in this table represent 1972 national totals and are characteristic of the data available at the BEA level. In addition, Tables 3 and 4 present U.S. totals for 1980 and 1985, respectively, based on the FEA reference scenario. The BTU conversion factors are given in Äpendix $C$.

The basic allocation procedure attempts to llake use of the bcct available data when deriving the overall energy consumption estimates. It was desired that the procedure developed satisfy the following criteria:

1. That readly available data sourceo bo utilized to allow for essy replication on a continuing annual basis;

2. That the methodology for preparing the energy statements be consistent with that used in preparing the reglonal projections;

3. That the initial structure be developed to utilize as much region specific information as possible, given the available time and resources; 
Table 2. Regional Energy Balance Table by Sector and Fuel, 1972

\begin{tabular}{|c|c|c|c|c|c|c|c|c|c|}
\hline Sector & $\begin{array}{c}\text { Distillate } \\
011\end{array}$ & $\begin{array}{l}\text { Residual } \\
\text { Oil }\end{array}$ & Gasoline & $\begin{array}{c}\text { Other } \\
\text { Hydro- } \\
\text { Carbons } \\
\text { (Trillions of }\end{array}$ & BTUs) & $\begin{array}{l}\text { Vatural } \\
\text { Gas }\end{array}$ & Coal & Electricity & $\begin{array}{c}\text { Total Fuel } \\
\text { Consumed }\end{array}$ \\
\hline \multicolumn{10}{|l|}{ Final Demand Sectors } \\
\hline $\begin{array}{l}\text { Residential, Comm. } \\
\text { Industrial }\end{array}$ & $\begin{array}{r}3191 \\
722\end{array}$ & 1176 & 0 & $1164^{1}$ & $\begin{array}{l}0 \\
0\end{array}$ & $\begin{array}{r}7642 \\
10591\end{array}$ & $\begin{array}{r}387 \\
4267\end{array}$ & $\begin{array}{l}2878 \\
2493\end{array}$ & 16438 \\
\hline $\begin{array}{l}\text { Industrial } \\
\text { Transportation }\end{array}$ & 1887 & $\begin{array}{r}190 \\
652\end{array}$ & 12821 & 1522 & 0 & 790 & 4 & 17 & 17693 \\
\hline Miscellaneous & 64 & 56 & 0 & 30 & 0 & 0 & 0 & 0 & 150 \\
\hline \multicolumn{10}{|l|}{ Total Final } \\
\hline Demand Sectors & 3004 & 3002 & $128<1$ & syss & 0 & 19023 & 4030 & 2580 & 54789 \\
\hline \multicolumn{10}{|l|}{ Transformation } \\
\hline Electricity Gen. & 398 & 2737 & 0 & 0 & 0 & 4102 & 7836 & -4848 & 10225 \\
\hline Petroleum Products & -5606 & -1839 & -12153 & -2206 & 24829 & 1220 & 0 & 0 & 4245 \\
\hline Natura1 Gas & 0 & 0 & 0 & -1518 & 0 & 1674 & 0 & 0 & 156 \\
\hline Syn-Gas & 0 & 0 & 0 & 0 & 0 & 0 & 0 & 0 & 0 \\
\hline \multicolumn{10}{|l|}{ Net Fuel Used } \\
\hline 1n Transformation & -5208 & 898 & -12135 & -3724 & 24829 & 6996 & 7836 & -4848 & 14626 \\
\hline Total Net Usage & 656 & 3980 & 668 & 229 & 24829 & 26019 & 12494 & 540 & 69415 \\
\hline \multicolumn{10}{|l|}{ Supply of Energy } \\
\hline Foss1l Fuel & 0 & 0 & 0 & 0 & 19977 & 24224 & 14999 & 0 & 59200 \\
\hline Hydroelectric & 0 & 0 & 0 & 0 & 0 & 0 & 0 & 931 & 931 \\
\hline Nuclear & 0 & 0 & 0 & 0 & 0 & 0 & 0 & 184 & 184 \\
\hline Geo. \& Solar & 0 & 0 & 0 & 0 & 0 & 0 & 0 & 0 & 0 \\
\hline Total Supply & 0 & 0 & 0 & 0 & 19977 & 24224 & 14999 & 1115 & 60315 \\
\hline Loss, Errors and Onissions ${ }^{2}$ & $-276(4 \%)$ & $-48(1 \pi)$ & $-542(4 \%)$ & $256(6 \%)$ & $-147(1 \%)$ & $-773(3 \%)$ & $1160(9 \%)$ & $600(11 \%)$ & 230 \\
\hline Total Net Supply & 276 & 48 & 542 & -256 & 20124 & 24997 & 13839 & 515 & 60085 \\
\hline Net Imports & 380 & 3932 & 126 & 485 & 4705 & 1022 & -1345 & 25 & 9330 \\
\hline
\end{tabular}

${ }^{2}$ Excludes aspialt.

${ }^{2}$ Percentage of loss, error or omissiors based on gross usage. 
Table 3. Regłonal Energy Balance Table by Sector and Fuきl, 1980

\begin{tabular}{|c|c|c|c|c|c|c|c|c|c|}
\hline Sector & $\begin{array}{l}\text { D1stiulate } \\
\text { oyl }\end{array}$ & $\begin{array}{l}\text { Residual } \\
011\end{array}$ & Gasolice & $\begin{array}{c}\text { Other } \\
\text { Hyero- } \\
\text { Carbons } \\
11 \text { lons of }\end{array}$ & BTUs) & $\begin{array}{l}\text { Ne.tural } \\
\text { Gas }\end{array}$ & Cวa1 & Electric1ty & Tota: Sector \\
\hline \multicolumn{10}{|l|}{ Final Demand Sectors } \\
\hline Residential, Comm. & 3111 & 1209 & 0 & 2083 & 0 & 6137 & 156 & 4662 & $1: 358$ \\
\hline Industrial & 973 & 1465 & 0 & 4241 & 0 & $1: 315$ & $40<4$ & 3133 & $2 \bullet 171$ \\
\hline Transportation & 2506 & 639 & $1: 753$ & 3516 & 0 & 681 & 3 & 15 & 20113 \\
\hline Miscellaneous. & 50 & 20 & 0 & 20 & 0 & 0 & 0 & 0 & 90 \\
\hline \multicolumn{10}{|l|}{ Total Final } \\
\hline Denand Sectors & 6640 & 3333 & 12753 & 9860 & 0 & 19133 & 4203 & 7810 & 63732 \\
\hline \multicolumn{10}{|l|}{ Transformation } \\
\hline Electr1city.Gen. & 745 & 2272 & 0 & 0 & 0 & 3614 & 11486 & -6095 & $1 . .022$ \\
\hline Petroleum Products & -5887 & -2229 & -12556 & -9565 & 27332 & 2822 & 0 & 0 &. $\mathrm{C} 63$ \\
\hline Natural Gas & 0 & 0 & 0 & 0 & 0 & 0 & 0 & 0 & 0 \\
\hline Syn-Gas & 0 & 0 & 0 & 0 & 0 & 0 & 0 & 0 & 0 \\
\hline \multirow{2}{*}{$\begin{array}{l}\text { Net Fuel Used } \\
\text { in Transforation }\end{array}$} & -5122 & -43 & -13556 & -0565 & 27232 & 6136 & 1149 & 5005 & \\
\hline & & & & & & & & & \\
\hline Total Net Usage & +518 & -3376 & +197 & +295 & +27332 & +25569 & 15689 & +1715 & $7 \$ 691$ \\
\hline \multicolumn{10}{|l|}{ Supply of Energy for } \\
\hline Fossil Fuel & 0 & 0 & 0 & 0 & 22976 & 24111 & 17975 & 0 & 65082 \\
\hline Hydroelectric & 0 & 0 & 0 & 0 & 0 & 0 & 0 & 1160 & $\mathbf{L 1 6 0}$ \\
\hline Nuclear & 0 & 0 & 0 & 0 & 0 & 0 & 0 & 1323 & 1323 \\
\hline Geo. \& Solar & 0 & 0 & 0 & 0 & 0 & 0 & 0 & 22 & 22 \\
\hline Total Supply & 0 & 0 & 0 & 0 & 22976 & 24111 & $17 \subseteq 75$ & 2505 & 67587 \\
\hline Loss, Errors and Omissions & 0 & $-15(.3 \%)$ & $-\quad 10(.1 \%)$ & $+557(6 \%)$ & 0 & 0 & $+486(.3 \%)$ & $+790(10 \%)$ & 1838 \\
\hline Total Net Supply & 0 & -15 & +10 & -557 & 22976 & $2+111$ & 17489 & 1715 & 65749 \\
\hline \multicolumn{10}{|l|}{ Net Imports } \\
\hline of Region & +518 & 3391 & 187 & +852 & +4336 & 1458 & $-1 \varepsilon 00$ & 0 & B942 \\
\hline
\end{tabular}


Table 4. Reglonal Energy Balance Table by Sector and Fuel, 1985

\begin{tabular}{|c|c|c|c|c|c|c|c|c|c|}
\hline Sector & $\begin{array}{l}\text { Distillate } \\
\quad 011\end{array}$ & $\begin{array}{l}\text { Residual } \\
\text { Oil }\end{array}$ & Gasoline & $\begin{array}{c}\text { Other } \\
\text { Hodro- } \\
\text { Carbons } \\
\text { (Trillions of BTUs }\end{array}$ & $\begin{array}{l}\text { Crude } \\
\text { Oil }\end{array}$ & $\begin{array}{c}\text { Nacural } \\
\text { Gas }\end{array}$ & Coal & Electricity & $\begin{array}{l}\text { Total Fue1 } \\
\text { Consumed }\end{array}$ \\
\hline $\begin{array}{l}\text { Total Final } \\
\text { Demand Sectors }\end{array}$ & 8489 & 3901 & 14440 & 12005 & 0 & 21273 & 4933 & 10310 & 75351 \\
\hline $\begin{array}{l}\text { Transformation } \\
\text { Electr1c1:y } \\
\text { Petroleum Products } \\
\text { Natural Gas } \\
\text { Syn-Gas }\end{array}$ & $\begin{array}{r}401 \\
-8625 \\
0 \\
0\end{array}$ & $\begin{array}{r}2295 \\
-4418 \\
0 \\
0\end{array}$ & $\begin{array}{r}0 \\
-14343 \\
0 \\
0\end{array}$ & $\begin{array}{r}0 \\
-11524 \\
0 \\
0\end{array}$ & $\begin{array}{r}0 \\
35880 \\
0 \\
0\end{array}$ & $\begin{array}{r}3219 \\
2768 \\
0 \\
-\quad 169\end{array}$ & $\begin{array}{r}15381 \\
0 \\
0 \\
261\end{array}$ & $\begin{array}{r}-7064 \\
0 \\
0 \\
0\end{array}$ & $\begin{array}{r}14232 \\
-\quad 260 \\
0 \\
92\end{array}$ \\
\hline $\begin{array}{l}\text { Net Fuel Used } \\
\text { In Transformation }\end{array}$ & -8222 & 2123 & -14343 & -11524 & 35880 & 5818 & 15642 & -7064 & 14064 \\
\hline Total Net Usage & 267 & 1778 & 97 & 491 & 35880 & 27091 & 20575 & 3246 & 89415 \\
\hline Jotal Supply & 0 & 0 & 0 & 0 & 26000 & $257 \dot{48}$ & 22236 & 4293 & 78277 \\
\hline Loss, Errors and Omissions & 0 & 0 & $4(1 \%)$ & $-13(.1 \%)$ & 0 & $-25(.1 \%)$ & $-139(.7 \%)$ & $1047(10 \%)$ & 866 \\
\hline Total Net Supply & 0 & 0 & 4 & 13 & 26000 & 25773 & 22375 & 3246 & 77411 \\
\hline $\begin{array}{l}\text { Net Imports } \\
\text { of Region }\end{array}$ & 267 & 1778 & 93 & 468 & 9880 & 1318 & -1800 & 0 & 12004 \\
\hline
\end{tabular}


4. That the format be flexible to permit ease of revision and update;

5. That the procedure be sufficiently general to address a variety of questions as to the regional impacts of alternative energy policies and problems, conservation efforts, changing fuel mix patterns, specific fuel shortages, etc.;

6. That the estimates of regional energy deficiencies and/or surpluses provide a meaningful characterization of potential problems encountered in a region under alternative energy futures;

7. That the system operate with efflciency lu facilitatc prompt andysis of alternative scenarins.

The complicated dimensions of the energy system and lack of consistent data sets make satisfaction of each of the above criteria difficult. However, the present structure provides a strong base which can be systematically improved as better data sets become available. In its present form, the ORNL procedure can provide estimates which are sufficiently detailed to address energy-related issues at the level of fuel aggregation reported. in Table 2 .

To regionalize state energy data, several inconsistencies in the data must be resolved. Few of the state-level sources of energy data maintain a single consistent framework for defining the dimensions of cnergy consumptinn. Therefore, to remap aggregate energiy dacd lu sulaggregates adequately, at least four dimensions of the energy use systell should be considered:

1. The regional reporting grid of collected data;

2. The consumption sector defined for répôrting Llet data;

3. The fuel classification defined in the data;

4. The particular fuel use as reported in the data.

Because regional patterns may differ significantly in any subaggregate of each dimension, the linconslstencies in the publishod historical data inust be rcsolvcd. In several instanccs, conflicts between these sources were readily evident, even after accounting for differences in definitions and coverage.

To minimize problems associated with inconsistent data sources, the approach used here has been to use a well-defined acl of state-levr.1 aggregates (from the Bureau of Mines) as control totals which constrain the level of individual disaggregate components, and use other sources (e.g., Edison Electric and the Department of Transportation) to help establish the relative distribution of the aggregates' to the disaggregated 
components. A similar procedure is followed in using the forecasted data based on the FEA scenarios. We have reformulated the detailed data reported in the National Energy Outlook to be consistent with the reporting scheme followed by the Bureau of Mines unless otherwise noted.

The definitions established for the purposes of this project are shown in Tables 5 and 6 . Each table represents the potential disaggregation for each of the four dimensions. While not all data have been retained at the lowest possible level of detail, it was determined that the entire scheme should be shown.

The basic procedure followed in the regional disaggregation analysis is to estimate the fuel consumption of each of the defined consuming sectors listed in Table 7 for each of the subregions. The details on fuels considered and the uses detailed are determined for each sector based on applicability (whether the fuel is used by the sector) and availability of data. Consequently, not all fuels and uses are considered, nor is the lowest level of detail outlined in the tables always utilized. The specific data considered is detailed as part of the documentation of the generated series.

\section{B. Regionalization of Energy Consumption}

Regional demand for energy is determined primarily by the level of activity occurring in each sector in the region. Regional variation in the basic demand levels and fuel mix are determined by such factors as regional differences in delivered fuel costs, heating and cooling degree days, income, and many institutional factors.

Traditional energy demand analysis and projection procedures estimate functional relationships between demand (i.e., consumption) and a set of regional variables that are postulated to determine regional demand. One can then forecast a time-series of future energy demand based on a projected series of the chosen causal variables.

Two practical considerations limit the usefulness of this traditional approach for the purposes of this project. First, sufficiently consistent data are unavailable at the desired level of regional and fuel use detail. One of the purposes of the project is to estimate such a data series. Secondly, although we could estimate formal relationships at the state level and subsequently modify them to fit substate areas, this approach would require more time and resources than available to handle the detailed sectoral and fuel use definitions necessary for adequate spatial analysis.

A simpler approach that embodies two simplifying assumptions has been adopted in the present research. The first assumption is that for each consuming sector considered (Table 7 ), the primary determinant of a subregion's share of the state's energy consumption is its relative share of the overall state level of activity in the sector. Additional variables are aesumed either uniform across the state (e.g., heating 
Table 5. Lefinitions of Fuel Use Categories

ALL USES ${ }^{*}$

A. Heat and Pawer

1. Heat

a. Space heating

b. Frocess heat
1. Caoking
i. Water heating
3. Drying
C. Manufacturing process heat

2. Power ${ }^{*}$

a. Lighting

b. Mecharical drive

E. Non-energy Dem.ar.d*

1. Feedstock

2. Direct constmption (e.g. Lubes and raxes in transportation and asphalt in the residential and commercial sector)

\footnotetext{
* Definitions include categories used in current analysis.
} 
Table 6. Fuel Classification

Fue1

Reporting Aggregate

\section{Coal}

Anthracite

Bituminous and lignite

Metallurgical coal ${ }^{*}$

\section{Electricity}

Electricity

Natural Gas

Natural Gas

Petroleum Products

Distillate fuel oil

Residual f'jel oil

Gasoline

Other hydrocarbon products

Jet fuel

Kerosene

Liquid petroleum gas

Asphalt and road oil *

Liquified refinery gases

Still gas*

Naptha

Special naptha*

Lubricants and waxes*

Coa1

*Currently these fuels are included only in forecast data based on FEA scenarios. Thus, comparison directly between historic and forecasted data in other hydrocarbons may be misleading.

Distillate fuel oil

Residual fuel oil

Gasoline

Other hydrocarbons

Other hydrocarbons

other hydrocarbons

Other hydrocarbons

Other hydrocarbons

Other hydrocarbons

other hydrocarbons

Other hydrocarbons

other hydrocarbons

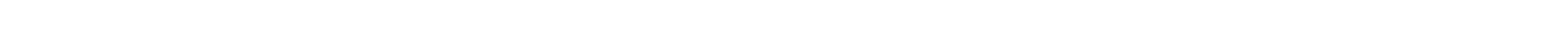


Table 7. Detailed Consuming Sectors Considered

\begin{tabular}{|c|c|}
\hline Sector & Activity Variable \\
\hline REŚSIDEN'I'IAL & Population \\
\hline \multicolumn{2}{|l|}{ COMMERCIAL AND GOVERNMENT } \\
\hline Wholesale and Retail Trade & Employment in Sector \\
\hline Finance, Insurance and Real Estate & Employment in Sector \\
\hline Services & Employment in Sector \\
\hline Federal Government & Euployment in Sector \\
\hline SI Ate and Local Government & Employment in Sector \\
\hline Armed Forces & Employmenl in scctor \\
\hline \multicolumn{2}{|l|}{ RESOURCCE ORIEN'ED INDUSTRIAL AC'I'IVITY. } \\
\hline Agriculture & Eupluyment in Sector \\
\hline Forestry and Fishcry & Empluyment in Sector \\
\hline Metal Mining & Employment in Sector \\
\hline Coal Mining & Employment in Sector \\
\hline Cruble $0 i 1$ and Gas & Employment in Sector \\
\hline Non-Metalic Mining & Employwerit in sector \\
\hline CONSTRUCTION & Employment in Sector \\
\hline \multicolumn{2}{|l|}{ MANUFACTURING ACTIVITIES } \\
\hline Food and Kindred Products & Employment in Sector \\
\hline Textilco & Employment in Sector \\
\hline Apparcl & Employment in sector \\
\hline Lumber and Furniture & Employment in Sector \\
\hline Paper Product.ts & Employment in Sector \\
\hline Printing and Publishing & Employment in Seclur \\
\hline Chemicals & Employment in Sector \\
\hline Patrolelum Refining & Employment in Sector \\
\hline Fabricated Metals & Employmène In Sectüi \\
\hline Primary Metals & Employment in Sector \\
\hline Machinery (non-electrical) & Employment in sector \\
\hline Electrical Machinery & Pinployment in Sertar \\
\hline Motor Vehirles & Employment in Sector \\
\hline Transportation Equipment & Employment in Seclur \\
\hline Other Manufacturing & Employment in Sector \\
\hline \multicolumn{2}{|l|}{ TRANSPOR'ATION } \\
\hline Automobiles & Population \\
\hline Truck and Bus & Employment in Transportation \\
\hline Rail and Transit & Employment in Transportation \\
\hline Air & Employment in Transportation \\
\hline Water & Employment in Transportation \\
\hline Pipelines & Employment in Crude $0 i l$ and Gas \\
\hline MTSCELLANEOUS & Population \\
\hline
\end{tabular}


degree days) or unimportant relative to differences in the level of activity (e.g., per capita income or regional price differences). This is a reasonable first approximation within states, but is clearly less appropriate between states.

The second assumption is that the effects of spatial differences in energy consumption between states can be measured in a simple aggregate comparison of state to state differences in energy use per unit of activity exhibited in historical data. Furthermore, we assume each state's relative position will remain constant during the period of forecast, unless specifically modified by scenario assumptions.

Under these assumptions the estimation of BEA consumption patterns can be performed in three steps. Initial energy demands in the first stage are estimated for each subregion using the historic patterns of energy use per unit of activity and the forecasted level of regional activity in each sector. ${ }^{22}$ Next, these subregion estimates of demand are adjusted to be consistent with the aggregate consumption totals provided by either the historic or forecasted data set. Adjusted demands are then interpreted as estimated consumption forecasts which are consistent with the aggregated energy consumption patterns. Finally, the consumption forecasts at the subregion level are aggregated to the desired level of spatial and sectoral detail. These three steps are discussed in detail below.

\section{STEP 1: ESTIMATION OF SUBREGIONAL DEMANDS}

The basic procedure is to estimate the demand for each fuel, sector, and use at as detailed a level as possible. This "demand" estimate represents each subregion's potential demand for a particular fuel in a given use in the sector of interest under the use patterns exhibited in the base year (1972) and the regional level of activity for the sector in the year of interest. Simply, we can say that this figure represents the demand for a sector's use of a particular fuel if it behaved as it did in the base year, but had the level of activity in the year under consideration.

For each subregion we specify a detailed set of relationships for each combination of fuel, sector, and use:

Demand $(\mathrm{S}, \mathrm{F}, \mathrm{U})=\operatorname{Level}(\mathrm{S}, \mathrm{F}, \mathrm{U}) \times \operatorname{Relative}(\mathrm{S}, \mathrm{F}, \mathrm{U}) \times \operatorname{Special}(\mathrm{S}, \mathrm{F}, \mathrm{U})$

$\times$ Activity (S)

Where

$$
\begin{aligned}
& \mathrm{S}=\text { sector (Table } 8 \text { ) } \\
& \mathrm{R}=\text { state to which subregion belongs } \\
& \mathrm{F}=\text { fuel. (Table } 7 \text { ) } \\
& \mathrm{U}=\text { fuel use (Table } 6 \text { ) }
\end{aligned}
$$


and $\begin{aligned} \text { Level }(\mathrm{S}, \mathrm{F}, \mathrm{U})= & \text { the average level of fuel } \mathrm{F} \text { used per unit of } \\ & \text { activity in sector } \mathrm{S} \text { for use } \mathrm{U} \text { as determined } \\ & \text { hy the natinnal average in the bace yoar }\end{aligned}$

Relative $(\mathrm{S}, \mathrm{F}, \mathrm{U})=$ the relative use per unit of activity of the state $\mathrm{R}$ compared to the national average, for the use $U$ of fuel $F$ in sector $S$

Special $(S, F, U)=$ a special variable applicable to a specific subregion for sector $S$, fuel $F$, and use $U$-if Special is set to zero, then the fuel is unavailable for use

Activity $(S)=$ the level of activity in sector $S$ (Table 8 ).

An intuitive explanation of this equation is that each demand represents the national average demand for energy given the level of activity in a region, with the average value modified according to state or substate deviations. Tables 8,9 , and 10 illustrate the use of the equation. Table 8 shows the amount of electricity used per unit of activity by each sector in the United States. ${ }^{2}{ }^{3}$ Table 9 indicates the amount of electricity used per unit of activity by each state (for three aggregated sectors). Table 10 shows the amount of electricity used per unit of activity by each state for detailed manufacturing sectors. As of yet we have not defined further distinguishing regional characteristics, although special consideration should be given to the increased use of electricity associated with uranium processing plants and intraurban Lranslt modes.

A variety of data sources were used to compute the 1eve1, relative, and special variables for defined sectors, fuels, and uses. This permitted the use of more specific regional detail, but increased the difficulty of maintaining comparable data definitions. Since the demands are controlled by Bureau of Mines state totals, however, the indices can be used to disaggregate the data set by sector, region, and fuel use, while maintaining consistency.

Documentation of the values for each of the defined indices and data sources will be presented as part of the individual data volumes for each historical and forecast year. In this report only the control data set will be discussed in detail.

\section{STEP 2: ESTIMATION OF CONSUMPTION}

The estimates of the energy demands by detailed sector and fuel for the year of interest are accumulated to aggregate sector, fuel, and regional totals consistent with the control data set definitions (either the historic or forecasted series). The relative differences between the sum of aggregate demand estimates are adjusted proportionally. These adjusted demands are referred to as estimates of consumption and may be 
Table 8. Electricity Used per Unit of Activity by Sector in 1972

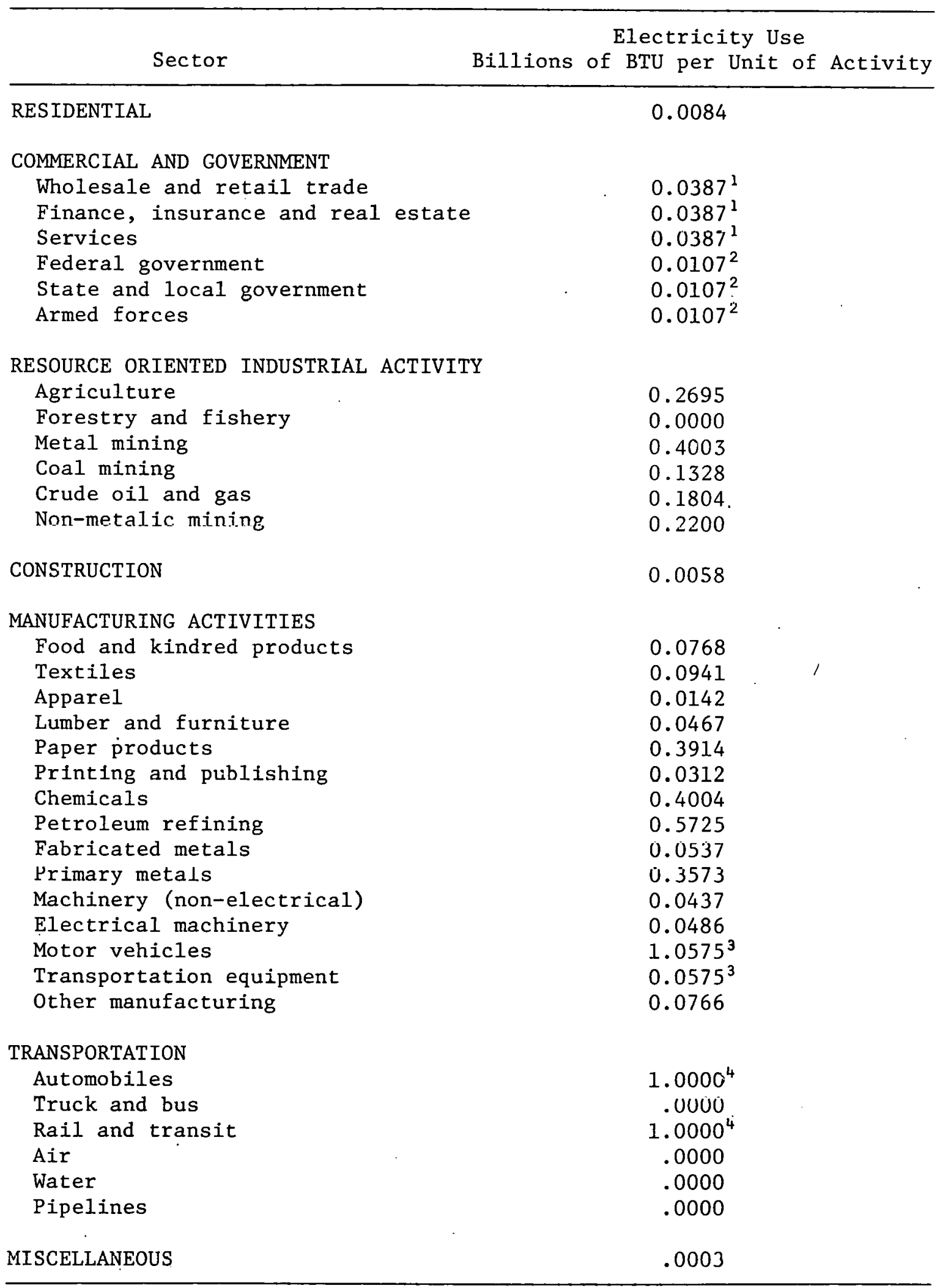


Table 8 (continued)

Notes:

1. Aggregate index for all commercial activities used for each sub-sector.

2. Due to data limitations, aggregate index for public authority use applied to all government sub-sectors.

3. Index for aggregate transportation equipment sectors (SIC 37) used for buth suli-sectors.

4. For automotive and rail and transit, dummy indices have been used. The effect of these is to allocate total use of elert.ricity hy pnpulation and emplnyment in transportation.

5. Miscellaneous category for electricity includes electricity used for street and highway lighting as well as interdepartmental use. 
Table 9. State Relative Use of Electricity per Unit of Activity by Sector in 1972

\begin{tabular}{|c|c|c|c|}
\hline State & Residential & Commercial & All Manufacturing \\
\hline Alabama & 1.40 & 1.17 & 1.65 \\
\hline Alaska & .89 & 1.22 & 1.00 \\
\hline Arizona & 1.16 & 1.52 & .77 \\
\hline Arkansas & 1.05 & 1.26 & 1.14 \\
\hline California & .77 & 1.21 & .75 \\
\hline Colorado & .71 & 1.15 & .60 \\
\hline Connecticut & .92 & .90 & .45 \\
\hline Delaware & .95 & .96 & 2.61 \\
\hline District of Columbia & .82 & .93 & .30 \\
\hline Florida & 1.65 & 1.06 & .75 \\
\hline Georgia & 1.23 & 1.27 & .80 \\
\hline Hawa11 & .71 & .46 & .27 \\
\hline Idaho & 1.55 & 2.27 & 4.15 \\
\hline Illinois & .81 & .92 & .70 \\
\hline Indiana & 1.03 & .91 & .98 \\
\hline Iowa & .97 & .78 & .82 \\
\hline Kansas & .97 & 1.39 & 1.06 \\
\hline Kentucky & 1.06 & 1.04 & 2.71 \\
\hline Louisiana & 1.18 & 1.16 & 2.61 \\
\hline Maine & .83 & .81 & .81 \\
\hline Maryland & .82 & .93 & .89 \\
\hline Massachusetts & .72 & .69 & .43 \\
\hline Michigan & .84 & .90 & .81 \\
\hline Minnesota & .09 & .52 & .61 \\
\hline Mississippi & 1.23 & 1.45 & 3.10 \\
\hline Missouri & .94 & .79 & .57 \\
\hline Montana & .97 & 1.19 & 8.11 \\
\hline Nebraska & 1.02 & 1.15 & .79 \\
\hline Nevada & 1.87 & 1.44 & 4.03 \\
\hline New Hampshire & .98 & .57 & .65 \\
\hline New Jersey & .76 & .94 & .63 \\
\hline New Mexico & .58 & 1.38 & .59 \\
\hline New York & .60 & .70 & .59 \\
\hline North Carolina & 1.29 & 1.31 & .81 \\
\hline North Daknta & .95 & .93 & .66 \\
\hline Ohio & .91 & .91 & 1.09 \\
\hline Oklahoma & 1.08 & 1.31 & .78 \\
\hline Oregon & 1.93 & 1.63 & 2.14 \\
\hline Pennsylvania & .84 & .76 & .78 \\
\hline Rhode Island & .65 & .79 & .45 \\
\hline South Carolina & 1.24 & 1.39 & 1.28 \\
\hline South Dakota & 1.00 & .83 & .41 \\
\hline Téthessee & 2.01 & .55 & 1.85 \\
\hline Texas & 1.19 & 1.34 & 1.70 \\
\hline Utah & .72 & .90 & .88 \\
\hline Vermont & 1.21 & .75 & .54 \\
\hline Virginia & 1.13 & 1.16 & .69 \\
\hline Washington & 2.07 & 1.55 & 2.72 \\
\hline West Virginia & .90 & 1.13 & 2.78 \\
\hline Wisconsin & .92 & .75 & .65 \\
\hline Wyoming & .82 & 2.22 & 1.57 \\
\hline
\end{tabular}


Tatle 10. Sta:e Relative Use of Elestric1ty per Unit of Activity Compared to the dationa: Average

Manufacturing Sectors

\begin{tabular}{|c|c|c|c|c|c|c|c|c|c|c|c|c|c|c|}
\hline State & $\begin{array}{c}\text { Food \& } \\
\text { KAndred }\end{array}$ & Textices & Apparel & $\begin{array}{c}\text { Lumber } \delta \\
\text { Furniture }\end{array}$ & Paper & Printing & Chemicals & Petroleum & $\begin{array}{l}\text { Zebrica:ed } \\
\text { Metals }\end{array}$ & $\begin{array}{l}\text { P:1mary } \\
\text { :1etals }\end{array}$ & Stacinirery & $\begin{array}{l}\text { Electrical } \\
\text { Machinery }\end{array}$ & $\begin{array}{l}\text { Transportation } \\
\text { Equipment }\end{array}$ & $\begin{array}{c}\text { Other } \\
\text { Manufactures }\end{array}$ \\
\hline Alabama & 0.89 & 1.41 & 1.30 & 0.14 & 2.08 & $\therefore .40$ & 2.11 & $0: 24$ & 1.10 & 1.28 & 1.23 & 1.03 & 0.61 & 2.03 \\
\hline $\begin{array}{l}\text { Arizone } \\
\text { Arkansas }\end{array}$ & 1.27 & $\star * .91$ & 0.51 & 1.23 & $*$ & 0.44 & 0.33 & * & 2.17 & 0.85 & 1.06 & 1.40 & 0.14 & 2.09 \\
\hline $\begin{array}{l}\text { Arkansis } \\
\text { Cal1fornia }\end{array}$ & 1.02 & $\begin{array}{l}1.91 \\
0.4^{7}\end{array}$ & 0.42 & 1.33 & 1.27 & c. 35 & 0.39 & 0.93 & 0.83 & 5.51 & 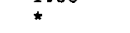 & 0.08 & 0.09 & 1.06 \\
\hline $\begin{array}{l}\text { Cal1fornia } \\
\text { Colorado }\end{array}$ & 0.87 & & $\begin{array}{l}0.45 \\
1.29\end{array}$ & 1.17 & 0.80 & C.97 & 0.54 & 1.66 & 1.21 & 0.63 & 0.88 & 0.95 & 0.91 & 1,42 \\
\hline $\begin{array}{l}\text { Colorado } \\
\text { Connecticut }\end{array}$ & 1.16 & 0.50 & 1.29 & * & 0.38 & C. 84 & 0.65 & 1.06 & 3.43 & 0.55 & 1.17 & 0.93 & 0.67 & .80 \\
\hline $\begin{array}{l}\text { Connecticut } \\
\text { Delaware }\end{array}$ & 0.76 & & $\begin{array}{l}0.41 \\
0.79\end{array}$ & 0.30 & 0.12 & 1.06 & 0.29 & 0.09 & 0.83 & 0.45 & 1.03 & 0.71 & 0.75 & .63 \\
\hline $\begin{array}{l}\text { Delaware } \\
\text { District of Columt la }\end{array}$ & 1.28 & & 9.79 & 4.22 & 1.84 & * & * & * & 1.06 & 1.95 & 0.86 & $\star$ & 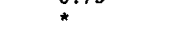 & 1.06 \\
\hline $\begin{array}{l}\text { District of Coluntia } \\
\text { Florida }\end{array}$ & 1.18 & * & 0.78 & * 91 & $*$ & 1.36 & $*$ & $* 7=$ & & & * & $\star 017$ & $*$ & 1.00 \\
\hline Georg1a & 0.87 & 1.15 & $\begin{array}{l}0.8 \\
1.16\end{array}$ & $\begin{array}{l}0.91 \\
0.40\end{array}$ & 0.59 & 0.72 & 1.09 & 0.73 & 1.14 & 0.92 & 0.08 & 0.17 & 0.12 & 1.55 \\
\hline Hawa11 & 0.72 & $\$ 1.10$ & & 0.40 & 1.06 & L. 70 & 0.85 & * & 1.10 & 0.59 & 0.87 & 1.43 & 0.87 & 1.24 \\
\hline Idaho & 1.49 & * & \pm .42 & $\$ 1.79$ & * & 0.42 & $*$ & * & 0.92 & * & 0.53 & * & * & 2.96 \\
\hline Illinols & 1.37 & 0.45 & 0.06 & 0.43 & 0.41 & $\begin{array}{l}4.03 \\
1.09\end{array}$ & 5.85 & 1.15 & $\begin{array}{l}0.92 \\
1.14\end{array}$ & 0.65 & $\begin{array}{l}0.53 \\
1.02\end{array}$ & 0.62 & 0.93 & $\begin{array}{l}8.03 \\
0.35\end{array}$ \\
\hline Ind1ana & 1.17 & * & 1.13 & 0.47 & 0.53 & $\begin{array}{l}1.09 \\
1.17\end{array}$ & $\begin{array}{l}0.42 \\
0.50\end{array}$ & 0.31 & 1.17 & 0.86 & 1.01 & 1.13 & 1.15 & $\begin{array}{l}0.35 \\
0.87\end{array}$ \\
\hline Iowa & 1.40 & * & $\because$ & 2.20 & 0.69 & 1.00 & 0.11 & $*$ & 1.20 & 1.55 & 0.86 & 1.00 & 0.75 & 1.24 \\
\hline Kansas & 1.52 & * & 1.10 & 1.80 & 0.33 & $*$ & $\begin{array}{l}.11 \\
1.18\end{array}$ & 0.96 & 1.19 & $* 08$ & 2.54 & * & 0.91 & 3.29 \\
\hline Kentucky & 0.36 & 1.69 & 1.09 & 0.26 & 1.29 & 1.50 & 8.65 & * & 1.62 & 1.74 & 1.29 & 1.72 & 1.30 & 1.85 \\
\hline Louistana & 0.57 & $*$ & 0.31 & 2.52 & 1.37 & 0.17 & 2.71 & 1.52 & 0.91 & 1.74 & $* 20$ & 1.74 & 0.54 & 1.57 \\
\hline MaIne & 0.33 & 0.53 & 0.92 & 0.51 & $\begin{array}{l}1.37 \\
1.58\end{array}$ & 095 & 0.29 & * & $\star * 1$ & 0.55 & 0.83 & $\star$ & 0.74 & 0.44 \\
\hline Maryland & 0.73 & $\star$ & 0.11 & 0.45 & $\begin{array}{l}1.38 \\
0.59\end{array}$ & $\begin{array}{l}104 \\
104\end{array}$ & 0.44 & * & 1.15 & $\begin{array}{l}0.55 \\
10.95\end{array}$ & $\begin{array}{l}.03 \\
1.06\end{array}$ & 0.79 & 1.00 & 1.27 \\
\hline Massach:1setrs & 1.29 & 0.57 & 0.94 & $\begin{array}{l}0.51 \\
0.51\end{array}$ & 0.44 & 088 & 0.29 & * & $\begin{array}{l}0.87 \\
0.87\end{array}$ & $\begin{array}{l}0.95 \\
0.24\end{array}$ & $\begin{array}{l}1.00 \\
0.79\end{array}$ & 0.88 & 0.78 & 0.54 \\
\hline $\begin{array}{l}\text { Michigas } \\
\text { Ment }\end{array}$ & 0.95 & 0.76 & $\begin{array}{l}1.61 \\
1.61\end{array}$ & 0.82 & 0.67 & 1.03 & 0.64 & * & $\begin{array}{l}1.86 \\
1.46\end{array}$ & $\begin{array}{l}0.24 \\
0.56\end{array}$ & $\begin{array}{l}.19 \\
1.03\end{array}$ & 0.88 & 1.46 & 1.67 \\
\hline Minnesota & 1.19 & 0.65 & 0.99 & 0.30 & 1.14 & 1.06 & 0.32 & 0.16 & $\begin{array}{l}1.40 \\
1.04\end{array}$ & 0.40 & $\begin{array}{l}1.03 \\
1.13\end{array}$ & 0.81 & 0.06 & 1.42 \\
\hline Mississipp1 & $1 . \approx 1$ & 0.86 & 1.40 & 1.74 & 0.55 & 0.34 & 1.82 & $\star *$ & 1.12 & 0.73 & 0.87 & 0.93 & 0.59 & $\begin{array}{l}1.42 \\
0.58\end{array}$ \\
\hline Missouri & 1.13 & 1. .09 & 1.31 & 0.53 & 0.03 & 0.22 & 0.29 & 0.31 & 1.19 & 0.87 & 0.83 & 0.84 & 0.81 & 1.34 \\
\hline Montana & 1.86 & $\therefore$ & 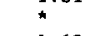 & 13.61 & $*$ & 7.49 & 0.11 & 7.21 & 1.85 & 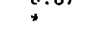 & $*$ & & & 9.24 \\
\hline Nebraska & 1.32 & : & 1.69 & 1.90 & * & 1.15 & 2.15 & * & 1.01 & c.55 & $0: 08$ & 0.95 & 0.65 & 1.24 \\
\hline Nevada & & * & * & $*$ & * & 1.17 & 3.33 & * & $* 0$ & .003 & $*$ & 0.29 & * & 2.01 \\
\hline New Kampshire & 1.48 & 0.73 & * & 0.10 & 2.18 & 0.78 & $\begin{array}{l}.35 \\
0.26\end{array}$ & * & 0.54 & $C .17$ & 1.100 & 0.73 & * & 0.46 \\
\hline New Jersey & 1.01 & 0.65 & 1.07 & 0.44 & 0.65 & 1.17 & $\begin{array}{l}0.26 \\
0.36\end{array}$ & 0.77 & 1.25 & c. 49 & 0.97 & 0.84 & 1.05 & 0.64 \\
\hline New Mexico & & T & $*$ & $*$ & $*$ & & & * & & $\star \pi$ & $*$ & * & $\approx$ & * \\
\hline New York & 0.89 & 0.43 & 1.25 & 0.83 & 0.63 & 0.72 & 0.49 & 0.96 & 1.36 & 1.14 & 0.95 & 1.20 & 1.11 & 0.63 \\
\hline North Carolina & 0.85 & $\therefore .08$ & 1.03 & 0.70 & 1.14 & 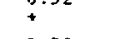 & 0.56 & * & 1.18 & 2.91 & 1.09 & 1.64 & * & 1.57 \\
\hline North Dekota & 1.34 & 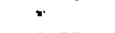 & $\because$ & $*$ & ${ }^{*}$ & 1.22 & $*$ & * & $*$ &. .91 & " & & * & 4.01 \\
\hline Oh10 & 0.88 & c. .55 & $0.1 \mathrm{i}$ & 0.62 & 0.56 & $\because .33$ & 1.50 & 1.30 & 1.31 & 0.92 & 1.25 & 1.00 & 1.23 & 1.03 \\
\hline Oklahoma & 0.93 & $\because$ & 0.23 & 0.59 & 2.33 & 0.25 & 2.08 & 1.01 & 0.91 & 0.80 & 0.35 & 0.66 & 0.91 & 1.22 \\
\hline Oregon & 0.98 & $c .83$ & 7.53 & 2.05 & 7.01 & 6.40 & 3.33 & 1.43 & 0.62 & $\begin{array}{l}0.80 \\
8.93\end{array}$ & 1.96 & 2.82 & 1.59 & 3.73 \\
\hline Pennsylvan1a & 0.79 & C. 57 & 0.81 & 0.44 & 0.75 & 1.35 & 0.40 & 0.67 & 1.24 & 0.61 & 1.02 & 1.17 & 0.79 & 1.13 \\
\hline Rhode Island & 0.10 & C. 68 & $\$ .76$ & 0.53 & 0.31 & 1.29 & 0.25 & $*$ & 1.24 & 0.38 & 0.10 & 0.88 & * & 0.65 \\
\hline South Carolina & $*$ & 11.60 & 1.75 & 1.23 & 2.07 & 0.27 & 0.64 & $\star$ & - & 3.34 & 1.30 & 2.01 & 0.81 & 1.80 \\
\hline South Dakota & 0.89 & 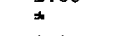 & * & 0.70 & * & C.<0 & .0 .04 & * & * & * & 0.74 & 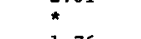 & ${ }^{*} .01$ & 1.14 \\
\hline Tennessee & 1.05 & 3.93 & 1.17 & 0.76 & 1.49 & 1.03 & 1.68 & 0.43 & 1.51 & 364. & $\therefore 29$ & 1.76 & 0.79 & 1.28 \\
\hline Texas & 1.13 & & 0.18 & 1.00 & 0.95 & 0.16 & 1.89 & 1.01 & 1.35 & 1.94 & 1.17 & 1.00 & 0.73 & 1.93 \\
\hline Utah & 1.01 & * & 0.92 & * & * & $0 . \subseteq 4$ & 1.07 & 1.47 & * & $*$ & $0 . .1$ & 0.17 & 1.15 & 2.29 \\
\hline Vermont & 0.28 & $*$ & 2.45 & 1.82 & * & $1 . \angle 8$ & $\begin{array}{l}1.01 \\
0.63\end{array}$ & * & * & 0.69 & 1.34 & * & & $1.6 ?$ \\
\hline Virgin1a & 0.69 & 3.83 & 1.08 & 0.51 & 0.96 & 1.06 & $\begin{array}{l}.03 \\
0.46\end{array}$ & * & 1.20 & 0.68 & 0.92 & 1.53 & 0.62 & 1.55 \\
\hline Washington & $\therefore .02$ & * & 1.05 & 1.47 & 3.30 & 0.70 & $\begin{array}{l}0.46 \\
1.88\end{array}$ & * & 1.27 & 7.60 & 1.84 & 0.36 & 1.48 & 0.65 \\
\hline West virzinta & & 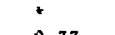 & 0.50 & 0.31 & $+\infty$ & 0.26 & $\begin{array}{l}1.88 \\
1.51\end{array}$ & 0.57 & 1.32 & $\begin{array}{l}2.00 \\
2.01\end{array}$ & 0.68 & 3.36 & $*$ & 1.09 \\
\hline Wiscons1a & 0.99 & 0.33 & 0.89 & 0.32 & 1.21 & $\begin{array}{l}.20 \\
1.67\end{array}$ & 0.38 & $*$ & 1.19 & 0.34 & 1.05 & 0.93 & 0.86 & 0.67 \\
\hline Wyoming & 0.81 & & & & & & $*$ & 1.28 & & & & & & 1.16 \\
\hline Average & $1.0 \bar{z}$ & 0.83 & 1.35 & 1.26 & 3.20 & 1.23 & 1.27 & 1.13 & 1.18 & 1.51 & 1.00 & 1.09 & 0.83 & 1.73 \\
\hline
\end{tabular}

*Decalled stat a data was no: arallajle. Consequently, these values $w=11$ be esolmated by an indrect procedure, 
viewed as representing estimated subregion consumption patterns which are consistent with the consumption control totals and the relative energy use patterns in the base year.

The controlling data set chosen for the historic data series is the state data provided in Fuel and Energy Data: United States by States and Regions: 1972. ${ }^{24}$ Since these Bureau of Mines data are for state areas, the state relatives are not actually used in spatial disaggregation, but the effect of the relatives in this case is important in disaggregating fuel and sector totals within the state.

The available level of regional and fuel definitions for the historic data used is presented in Table 11. Also shown are the levels of energy use in the United States in 1972 as determined by the Bureau of Mines. The forecasted regional energy patterns are based on the FEA base case (\$13 per barrel for oil) forecasts for 1980 and $1985 .{ }^{25}$ The finest regional detail used by $\mathrm{FEA}$ is the census region. The state relatives are, therefore, quite important in the regional disaggregation, as well as in the sector and fuel decompositions. Table 12 presents the fuel and sector definitions of FEA and the forecasted energy levels in 1985 for the nation as a whole.

\section{STEP 3: ESTIMATES OF BEA ENERGY CONSUMPTION PATTERNS}

The last stage of analysis is to aggregate subregional estimates to the national level, census regions, states, and BEAs bringing together the estimates of both consumption and supply to formulate the regional energy balance statements. We then compare the total demand for energy with the actual consumption. The difference between these values indicates how much change in established patterns of energy use must be undertaken through conservation or legislation. Alternatively, if we assume that energy use patterns will not change significantly, we can compute the number of workers likely to be affected by the anticipated shortage.

While it is true that some adjustment in lase year cncrgy use patterns will occur in the event of a shortage, these measures provide a simple way of denoting the range of extremes. The aggregation of activity loss, however, requires caution. Residential and industrial activity cannot be aggregated, nor can the loss in employment associated with a shortage of fuel for heat and power be added to the employment loss associated with a shortage of fuel used as feedstock.

An example of the methodology for measuring impacts at the regional level is provided by a comparison of state level forecasts derived from the census region scenarios for 1985. Estimated 1985 total demand (unconstrained) for natural gas in California based on the 1972 energy use patterns is 1.26 times that of the forecasted consumptions (constrained to the scenarios). 
Table 11. Aggragate Fuel and Sectors Defined

Historic Data

United States Total Consumption

1972

(Trilitions of BTUs)

\begin{tabular}{|c|c|c|c|c|c|}
\hline Fuels & $\begin{array}{c}\text { Residential } \\
\dot{\alpha} \\
\text { Commercial }\end{array}$ & Industrial & Transportazion & Miscellaneous & Undistributed $^{\text {l }}$ \\
\hline Anthracite & C & 0 & 0 & 162.0 & 52.0 \\
\hline Bituminous & 210.5 & $38 E=.6$ & 0 & 0 & 9579.5 \\
\hline Electricity & $34: 8.1$ & $249 \approx .7$ & 16.9 & J & .3 \\
\hline Natural gas & 7613.1 & 10545.5 & 787.0 & 1] & 73.2 \\
\hline Petroleum products & 6716.7 & 3157.0 & 16881.0 & 149.5 & $2927.6^{2}$ \\
\hline Distillate fuel oil & $3 I S 1.0$ & 722.1 & 1886.6 & 63.5 & \\
\hline Residual fuel oil & 1176.4 & 1198.3 & 651.5 & $55 . ?$ & \\
\hline Gasoline & 0 & 0 & 12821.1 & 0 & \\
\hline Jet fuel & 0 & 3 & 1380.6 & 0 & \\
\hline Kerosene & 375.3 & 111.4 & 0 & 0 & \\
\hline Liquid petroleum gas & 788.2 & 1125.2 & 141.2 & 30.3 & \\
\hline Asphalt & 1185.8 & 0 & 0 & 0 & \\
\hline TOTAL & 24735.1 & 23219.8 & 34565.9 & 461.2 & 12632.6 \\
\hline
\end{tabular}

${ }^{1}$ Undistributed refers to the zmount of fue- used in the United States which is not distributed to individual states by the Bureau of Mines.

${ }^{2}$ Undistribisted amount show for all petroleum products, amount Eor individual products not available. 
Table 12. FEA 1985 Scenario

(Trillions of BTUs)

\begin{tabular}{|c|c|c|c|c|c|}
\hline Fuel & $\begin{array}{c}\text { Residential } \\
\& \\
\text { Commercial }\end{array}$ & $\begin{array}{l}\text { Industrial } \\
\text { Heat \& Power }\end{array}$ & $\begin{array}{l}\text { Industriál } \\
\text { Non-Energy }\end{array}$ & Transportation & Miscellaneous \\
\hline Anthracite & 46.52 & 4.94 & - & - & - \\
\hline Bituminous & 67.60 & $3,229.97$ & - & 2.42 & -- \\
\hline Metallurgical & -- & -- & $1,582.01$ & -- & - \\
\hline Electricity & $6,432.38$ & $.3,863.86$ & - & 14.42 & - \\
\hline Natural gas & $6,440.32$ & $12,984.87$ & 15.01 & 811.14 & $1,021.99$ \\
\hline Distillate fuel & $4,266.39$ & $1,297.89$ & -- & $2,875.37$ & .50 .01 \\
\hline Residual fuel & $1,460.94$ & $1,785.43$ & - & 634.68 & 20.00 \\
\hline Gasoline & -- & -- & -- & $14,440.24$ & - \\
\hline Jet fuẹl & -- & -- & - & $4,037.06$ & - \\
\hline Kerosene & 214.76 & 100.16 & - & - & - \\
\hline Liquid gas & $1,048.71$ & 390.39 & - & 209.97 & 19.99 \\
\hline Liquid refinery gas & -- & -- & 196.25 & - & - \\
\hline Liquid petroleum gas & -- & $1,030.31$ & -- & - & - \\
\hline Asphalt \& road oil & $1,241.66$ & -- & -- & -- & -- \\
\hline Still gas & -- & $1,334.06$ & 88.60 & -- & - \\
\hline Naphthas & -- & -- & 397.68 & - & -- \\
\hline Special napthas & -- & -- & 211.84 & -- & - \\
\hline Lubes and waxes & -- & -- & 276.87 & 169.68 & -- \\
\hline Petroleum coke & -- & 397.30 & 241.33 & - & -- \\
\hline Raw material & - & - & - & - & 398.28 \\
\hline TOTAL & $21,219.28$ & $26,419.18$ & $3,009.59$ & $23,194.98$ & $1,510.27$ \\
\hline
\end{tabular}


This means that to realize the activity levels currently projected, a more than $20 \%$ savings in natural gas use must be achieved through increases in energy efficiency.

In terms of sector differences the largest efficiency gains must be realized in the residential and commercial sectors. To be consistent with the FEA scenario a 46\% savings in natural gas usage relative to 1972 patterns must occur in the residential and commercial sectors. In contrast, a slight increase of about $2 \%$ is implied for the industrial sector.

In essence, these efficiency changes suggest the need for extensive conservation efforts. Such efforts will differ among individual subregions of each state, depending on mixes of regional activity and historic dependence on particular energy forms.

Given the structure of the analysis, further implications as to the regional consequences of national energy scenarios are possible. The ORLN procedure can provide a convenient methodology for addressing these impacts upon regional conservation efforts and employment activity and subsequent development. ${ }^{26}$ 


\section{SUMMARY AND CONCLUSIONS}

The research discussed in this volume was sponsored by the Economic Development Administration to develop information and analyses on the availability of basic and converted energy resources and to determine the relationship between these resources and regional economic development. A major goal has been to analyze the degree to which energy availability may hamper the implementation of economic development plans. This program has been designed to develop information that will assist EDA in determining suitable target areas for future infrastructure development investment.

\section{A. Summary of Progress}

The statements of regional energy use and availability developed in this study represent the first attempt at constructing a national and regional accounting system for functional economic areas. Our past research has led to: (1) the construction of an historical energy data base appropriate to addressing development issues; (2) a basic methodology for formulating regional energy statements; and (3) acceptable procedures for examining regional availability and projecting regional energy use. We have now assembled sufficient information and developed the requisite expertise to conduct analyses of regional energy production, transformation and consumption.

During the first twelve months of the project, ORNL compiled regional energy statements for census regions, states, and BEAs for 1972 and developed a methodology for projecting regional energy use and availability. In addition, we examined the uses of energy forms in somewhat more detail than requested in our original agreement with EDA. In order to provide consistent regional energy statements for each historical year, it was necessary to recalculate the energy use statistics. The ability to better analyze the changes occurring in energy use across regions and across time was felt to be of sufficient import to justify a delay in publishing our 1972 data. However, we expect to publish the 1972 volume in the near future.

Our agreement for the second twelve months of the project involves extending our data set to 1973 and 1974 , and projecting regional energy use and availability to 1980 and 1985 based upon the methodology developed during the first year of the project. In addition, a preliminary analysis of natural gas availability in the past and future is scheduled to determine which regions will experience the most critical shortages of natural gas and the potential options for dealing with projected curtailments.

A detailed work plan of our second year of activity is shown in Table 13. We anticipate that by July 1, 1977, we will have completed four data volumes to accompany this methodological and data overview, as well as a volume containing an analysis of natural gas availability based 
Table 13. Scheduling of Activities ${ }^{1}$

\begin{tabular}{|c|c|c|c|c|}
\hline Output & 1972 Volume & 1973 Volume & 1974. Volume & 1980-1985 Valume \\
\hline Energy Surply Data & Ready & Ready & Ready & Ready \\
\hline Energy Demand Data & May 1 & June 1 & June 1 & May 15 \\
\hline $\begin{array}{l}\text { Computer Frogram to } \\
\text { Output Statistics } \\
\text { Reconciling }\end{array}$ & & & & \\
\hline Supply anci Demand & May 7 & June 7 & June 7 & May 22 \\
\hline $\begin{array}{l}\text { Manuscript Accompanyirg } \\
\text { Volumes }\end{array}$ & May 1 & June 1 & Juge 1 & May 30 \\
\hline $\begin{array}{l}\text { Ready for Printing } \\
\text { Allow } 6 \text { Weeks for } \\
\text { Printing }\end{array}$ & May 7 & June 7 & Juge 7 & May 22 \\
\hline Distributíon of Data & June 21 & July 21 & July 21 & July 7 \\
\hline
\end{tabular}

${ }^{1}$ Work: proposed for the first and second years of the project will extend 27 months rather than 24 months to adjust the fiscal year for EDA with the October to September fiscal year used by most ORNL projects. This has been agreed Ło in principa- by EDA staff. 
on the historical data and our regional projections. The next step is to conduct similar research into the distribution of energy to better determine regional energy availability.

\section{B. Proposed Future Activities}

The term "energy availability" has been used somewhat ambiguously throughout the agreements funding this research. We are aware that "availability" means more than the point of energy production or transformation. We believe that future research must focus on the transportation of final energy forms to points of final use, as well as the trade-cffs in energy forms required by inadequate energy supplies or by conservation measures. We are planning to actively investigate the transportation issue to fully explore the concept of availability and associated constraints on regional economic development.

We plan to approach the availability issue in a manner similar to that used in analyzing regional energy production and consumption. We will first construct a data base of the historical energy transportation flows, and then proceed to a projection mode in which assumptions can be modified. We believe this approach superior to optimizing the network flow since optimization approaches reduce the importance of historical patterns.

A simple example may illustrate the inherent difficulties. If distance is in itself a significant aspect of energy cost and a determinant of final energy usage, one would expect utilities located near coal mines to use coal extensively. Nonetheless, the Tennessee Valley Authority is located in close proximity to eastern coal producing areas, but employs nuclear fuel rather than coal in most planned plant expansions. ${ }^{27}$ Considerable uncertainty characterizes the projections of energy forms available and those actually used in any given region, despite proximity.

Our detailed proposal, which is contained under separate cover, proposes to extensively analyze the energy distribution network and determine future transportation fluws of energy. By synthesizing network distribution models for each energy form with the regional energy statements we have already developed, we will be able to analyze the impact upon regional economic development of: (1) changes in the input of distribution networks, (2) changes in the pattern of energy distribution which result from administrative action, and (3) changes in energy consumption patterns which result from energy shortages.

Focusing first on natural gas, we will examine the natural gas pipeline network-its capacity, accessibility, and throughput. We will also analyze the proposed curtailments of natural gas and the number and location of electric utilities which will be ordered to convert to other fuel forms, as well as the available fuel alternatives of regions affected by changes in natural gas production and distribution. We will then conduct similar analyses of the distribution network of coal and petroleum products to permit a complete evaluation of energy availability. 
In addition to our analysis of availability, we will update our data set to 1975 and adjust our 1980 and 1985 projections of regional encrgy use and availability when FEA makes available its most recent projections of energy supply and demand. We will use MULTIREGION projections of population and employment, rather than OBERS projections, to disaggregate these national supply and demand factors. Finally, discussions between EDA and ORNL have led to mutual interest in exploring water as a constraining influence both to energy development and subsequent economic development. During the third year of the project we will prepare a brief discussion paper outlining a parallel effort to examine the effects of water availability on economic development. 


\section{FOOTNOTES}

${ }^{1}$ Federal Energy Administration, 1976 National Energy Outlook, FEA-N-75-713, Washington, D.C., February, 1976.

${ }^{2} \mathrm{~A}$ broad range of national energy-related models have been constructed over the past few years, most notably, the Reference Energy System of Brookhaven National Laboratory and the Project Independent Evaluation System of FEA.

${ }^{3}$ The Bureau of Mines publishes a number of statistical series regarding energy production and use such as Fuel and Energy Data: U.S. By States and Regions: 1972, IC-8647, 1974.

${ }^{4} \mathrm{~A}$ description of BEA areas, their origin and characteristics, and a rationale for their use is presented in $\mathrm{R}$. J. 0lsen, et. al., MULTIREGION: A Simulation Forecasting Model of Regional Population and Employment, ORNL-RUS-25, Oak Ridge National Laboratory: Oak Ridge, Tennessee, 1975.

${ }^{5}$ Ibid.

${ }^{6}$ The data gathered in preparing these regional energy statements will be contained in forthcoming ORNL data volumes.

${ }^{7}$ Federal Energy Administration, op. cit.

${ }^{8}$ MULTIREGION regionalizes national economic and demographic control totals. The national economic forecasts are drawn from the INFORUM model (see Clopper Almon, et al., 1985 Interindustry Forecasts of the American Economy, Lexington-Heath Publishing Company: Boston, Massachusetts, 1974).

${ }^{9}$ U.S. Bureau of Mines, Minerals Yearbook: Area Reports-Domestic, 1972 and 1973 editions, U.S. Government Printing Office: Washington, D.C., 1974 .

${ }^{10} 1976$ Keystone Coal Industry Manual, McGraw-Hill Publishing Company: New York, New York, 1976. This manual is published annually.

${ }^{11}$ Arkansas Oil and Gas Commission, Annual Oil cind Gas Report; Kansas Geological Survey, 1972 Oil and Gas Production in Kansas, University of Kansas; Loulsiand Department of Conservation, "Crude, Condensate, Calculated Theoretical Condensate, Casinghead Gas, and Natural Gas Production by Parishes," 1972, 1973, and 1974; Oklahoma Corporation Commission, Quarterly Summary of Liquids and Gas Runs by Counties: 1972, 1973, and 1974; Texas Railroad Commission, Annual Report of the Oil and Gas Division. 
${ }^{12}$ Oil and Gas Journal, selected issues, The Petroleum Publishing Company: Tulsa, Oklahoma, weekly.

${ }^{13}$ Kenneth K. Landes, Petroleum Geology of the United States, Wiley Publishing Company: New York, New York, 1970; E. N. Tiratsoo, Oilfields of the World, Scientific Press, Ltd: Beaconsfield, England, 1970.

${ }^{14}$ Natural gas is produced in Maryland and Virginia where no crude oil is produced. Crude oil is produced in Nevada and South Dakota, where no natural gas is produced. The other 28 states referred to produce both crude oil and natural gas.

${ }^{15}$ U.S. Bureau of Mines, "Natural Gas," preprint frnm the 19.74 Minerale Yearbook.

${ }^{16}$ The Bureau of Mines reports one figure for Florida, Geurgla, and Virginia, one for Kentucky and Tennessee, one for Missouri and Nebraska, one for Minncsota and Wisconsin, one for Alaska, Washington, Orcgon, Arizona, and Hawaii, and one for Delaware and Maryland.

${ }^{17} 0$ il and Gas Journal, op. cit.

${ }^{18}$ International Petroleum Encyclopedia, The Petroleum Publishing Company: Tulsa, Oklahoma, 1975.

${ }^{19}$ The number, location, ownership, and crude distillation capacity of individual refining plants is published annually by both the Bureau of Mines and the Oil and Gas Joumal. There are minnr discrepancica beiween cápacity estimates of these two sources, given that thw Bureau of Mlues focuses on capacity per calendar day, while the oil and Gas Joumal focuses on capacit.y per stream day.

20 "Form 4" is a computer tape file available from the Federal Power Commission containing information on electric utilities by plant.

${ }^{21}$ Generating Unit Reference File is a computer tape availahle from the Fedelal power commission containing information on electric utilities.

${ }^{22}$ Given the data availability, the indices were constructed using information from several different years. The residential and commercial data presented in Table 2 is hased on 1972 data from Edison Electric Institute, while the manufacturing data is available only for 1971 from State Projections of Industrial. Fix.7. Noeds, Federal Power lommissiun. It is assumed that any year to year variation is relatively small and that 1971 is a good proxy for 1972 . 
${ }^{23}$ The level of economic activity is either population or employment. In the case of the historic data, we aggregate the County Business Patterns employment to the desired level of detail. For the forecast years 1980 and 1985, we have estimated sub-region population and employment by detailed sector, based on the OBERS regional population and earnings forecasts at the state and BEA level.

${ }^{24}$ The basic data on petroleum in fuel and energy data has been supplemented by a more detailed breakdown provided on computer tapes from the Bureau of Mines.

${ }^{25}$ The 1980 estimates are not presented in the 1976 National Energy outzook, but may be obtained directly from FEA.

${ }^{26}$ The forecasted regional employment currently used in the analysis is based on the OBERS forecasts. We intend to eventually utilize the ORNL-MULTIREGION model to increase the predictive power of our model.

${ }^{27}$ TVA also seems to have made a commitment to use low sulfur coal in existing coal-fired stations rather than rely extensively on pollution control technology, even though the bulk of low sulfur coal is. located in the. west. 


\section{PAGES 42 to 44 WERE INTENTIONALLY LEFT BLANK}




\author{
APPENDIX A \\ DATA SOURCES FOR OIL AND GAS SUPPLY
}

1973 and 1974

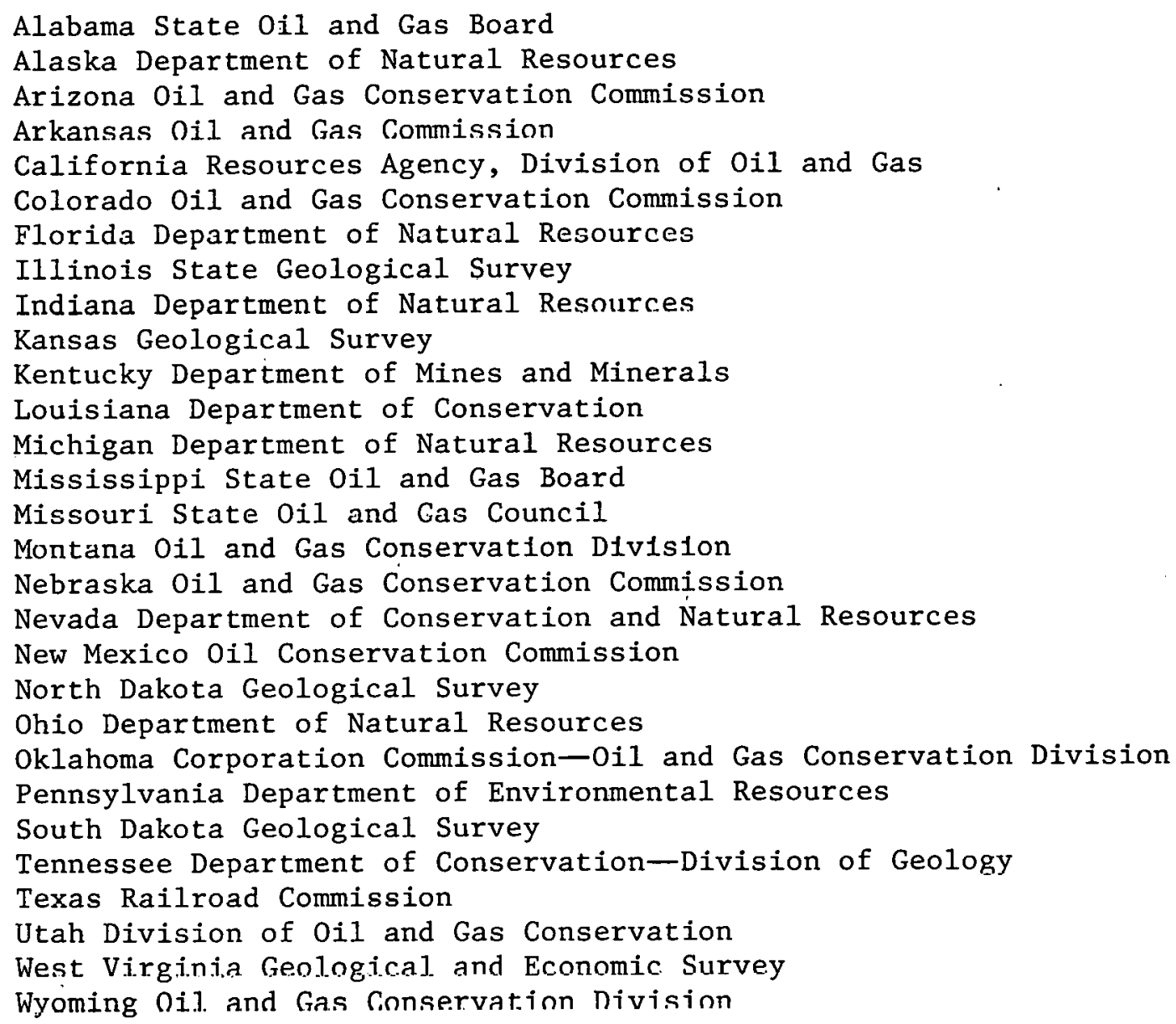

29 of the 30 oil producing states accounting for $99.9 \%$ of oil production. 


\section{THIS PAGE}

\section{WAS INTENTIONALLY \\ LEFT BLANK}


The regional energy balance statements depicted in Tables 2, 3, and 4 were constructed to provide a simple, consistent methodology for examining and comparing regional energy patterns. For each region we will show where energy is used, in what fuel form it is used, and how it is provided to the region.

The underlying structure is somewhat unique to our representation and requires further elaboration. All energy data is internally processed in British Thermal Units (BTUs), and the regional energy tables will also be presented in BTUs. Average conversion measures are incorporated such that these tables may also be presented in the traditional units for each fuel.

The basic sectors: the final demand sector, the transformation sector, and the energy supply sector, correspond to the discussion in the text. Consumption in the final demand sectors is for final end use, but the transformation sectors use energy in one form, then supply it to the final demand sectors in another. Consequently, total energy usage in the transformation sector is defined as the conversion loss in the process and considered part of final regional demand. In the transformation sector, a positive number represents input to the conversion process and a negative number represents the output of the transformation process.

The energy supply sector consists of fossil fuel production and electricity generated by hydropower, nuclear energy, solar and geothermal sources. The electricity conversion rate is that of end use (3.412 BTU/ $\mathrm{kwh}$ ) rather than fossil fuel equivalents. It was not felt essential to our overall goal of portraying regional energy conditions to trace the flow of uranium from point of extraction to point of processing to point of end use, since most BEAs must import enriched uranium.

The tables indicate the total amount of fuel consumed in each sector as well as the consumptions of each specific fuel. For example, the residential sector consumed 16,438 trillion BTUs of total energy in 1972, primarily natural gas (7,642 trillion BTUs). None of the final demand sectors consume unprocessed crude oil. The total energy consumption of all sectors is presented in the row labeled "Total Final Demand" (54,789 trillion BTUs). Natural gas consumption (19,023 trillion BTUs) accounted for the greatest single share of the total in 1972 .

The coefficient signs of the numbers in the transformation sector indicate whether the fuel is an input or an output of the transformation process. A positive number represents an input (i.e. demand) to the conversion process, while a negative number represents an output (i.e. supply or a negative demand) of the process. The sector total is the total output minus all inputs measured in BTUs. For example, in the 
electricity sector the output is total generated electricity by fossil fuel plants in BTUs minus the BTU content of the fuels consumed. The output (demand) of electricity by fossil fuel plants in 1972 was 4,848 trillion BTUs, while inputs were 398 trillion BTUs of distillate oil, 2,737 trillion BTUs of residual oil, 4,102 trillion BTUs of natural gas and 7,836 trillion BTUs of coal. The total BTUs 1ost in the conversion operation, and treated as consumption by the sector was 10,225 trillion BTUs. This loss implies an efficiency in electricity transformation of fossil fuels of 47 percent.

The amount of BTUs lost in a conversion process may reflect either the actual conversion loss, as in the case of the electric generating plants, or may include unaccounted for outputs. In particular, for the case of petroleum products we have not included asphalt, although the crude oil input reflects this potential output. The consumption of asphalt is included as part of the total consumption of the petroleum transformation sector, rather than part of a final demand sector. The net consumption of fuel used in the oil transformation sectors is presented in the row labeled "Net Fuel Used." The total net regional demand for fuel minus the supply of fuels by the transformation process is presented in the row labeled "Total Net Usage" (69,583 trillion BTUs). This energy is the amount which came from primary sources or foreign imports.

\section{SUPPLY AND IMPORTS}

The total supply by all forms of primary energy is given in the row labeled "Total Supply." Distillate oil, residual oil, gasoline and other hydrocarbons are all zero, indicating that these products are not considered primary energy sources.

The tables were constructed to balance, i.e., the sum of row totals will equal the sum of column totals. Consequently, the last.row represents the net regional imports by fuel (a negative number indicates exports). With the exception of the national tables, these values do not represent measured imports or exports, but are derived from the consumption and supply data. 'The number in the last row and last column gives a single measure of net energy imports of a region, characterizing the region as to its external reliance upon energy supplies. The U.S., a net importer of energy, acquired 9,330 trillion BTUs of energy products from foreign sources in 1972. To maintain consistency with measured imports at the national level, the tables are constructed such that the tables report estimated net imports equal to the actual data. Any initial differences between estimated and actual net imports are allocated based on each region's share of total gross usage of each fuel and reported in the row labeled "Loss, Errors, and Omissions." The transmission loss associated with electricity generation is based on the national average loss and imputed to the consuming region, and is also reported in the row labeled "Loss, Errors, and Omissions." 
APPENDIX C

CONVERSION FACTORS

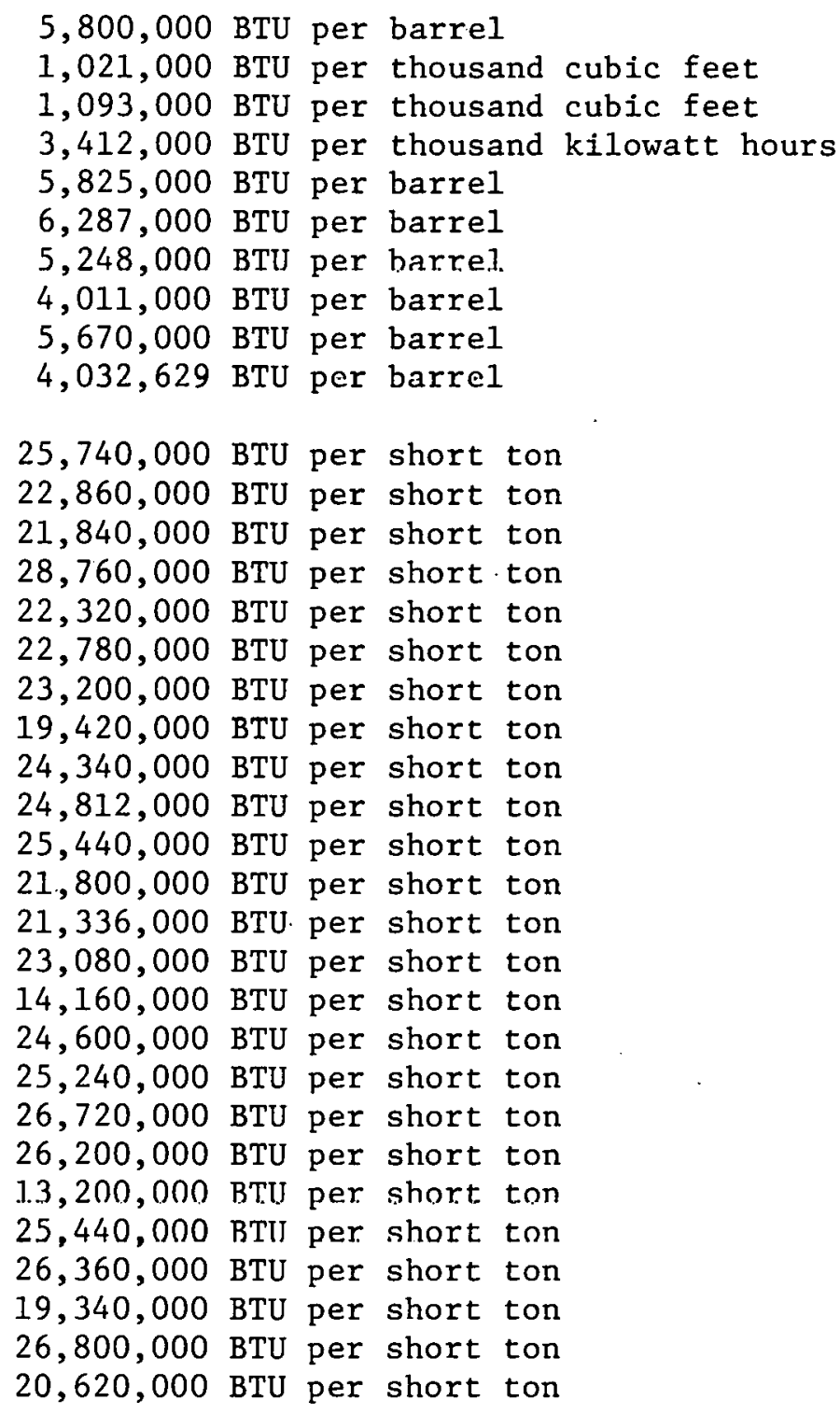

The conversion factors for coal consumption are the same with the following exceptions: Massachusetts, Maine, New Hampshire, Rhode Island, Vermont, Delaware, District of Columbia and Maryland-26.8; Kentucky, South Carolina, Tennessee, Florida and Georgia-25.46; Idaho, Montana and Minnesota-20.58; Iowa, Missouri and Wisconsin-22.78; New Jersey and New York-26.72; Oregon and Washington-20.58; California-25.4; Connecticut-26.12; Michigan-24.6; North Carolina-24.34 million BTUs per ton. 
THIS PAGE

\section{WAS INTENTIONALLY \\ LEFT BLANK}




\section{INTERNAL DISTRIBUTION}

1. S. I. Auerback

2. S. E. Beall

3. L. G. Berry

4. C. R. Boston

5. B. H. Bronfman

6. A. A. Brooks

7. C. A. Burwe11

8. R. S. Carlsmith

9. W. S. Chern

10. J. T. Cowan

11. C. G. Crafton

12. F. L. Culler

13. R. M. Davis

14. R. C. DeVault

15. J. E. Dobson

16. W. Fulkerson

17. H. H. Herzog

18. E. A. Hirst

19. N. E. Hinkle

20. R. B. Honea

21. D. G. Jacobs

22. D. L. Kaserman

23. C. R. Kerley

24. M. J. Ketelle

25. A. S. Loeb 1

26. L. A. Martin

27. J. R. McWherter
28. J. W. Michel

29. C. S. Oen

30. D. C. Parzyck

31. E. B. Peelle

32. H. Postma

33. B. J. Purdy

34. P. L. Rice

35. C. R. Richmond

36. M. W. Rosenthal

37. T. H. Row

38. R. M. Rush

39. M. A. Shields

40. R. L. Spore

41. R. E. Thoma

42. R. I. Van Hook

43. A. H. Voelker

44. D. P. Vogt

45. H. E. Zittel

46- 47. Central Research Library

48. Document Reference Section

49- 50. Laboratory Records

51. Laboratory Records - RC

52. ORNL Patent Office

53-247. Regional Economic Analysis Group Regional and Urban Studies Section Energy Division

\section{EXTERNAL DISTRI BUT ION}

248. Director, Research and Technical Support Division, ERDA-ORO.

249-275. Technical Information Center, ERDA-ORO.

27G-400. Reyiunal and Urban Studies Vistribution, Energy Division. 